\title{
Impact of precession on the climate, vegetation and fire activity in southern Africa during MIS4
}

\author{
M.-N. Woillez ${ }^{1,2,3}$, G. Levavasseur ${ }^{4}$, A.-L. Daniau ${ }^{1}$, M. Kageyama ${ }^{5}$, D. H. Urrego ${ }^{1,2,3}$, M.-F. Sánchez-Goñi ${ }^{2}$, and \\ V. Hanquiez ${ }^{1}$ \\ ${ }^{1}$ Centre National de la Recherche Scientifique (CNRS), Environnements et Paléocenvironements \\ Océaniques et Continentaux (EPOC), Unité Mixte de Recherche, UMR5805, CNRS - Université Bordeaux 1, \\ 33400 Talence, France \\ ${ }^{2}$ Ecole Pratique des Hautes Etudes (EPHE), EPOC, UMR 5805, 33400 Talence, France \\ ${ }^{3}$ CNRS, de la Préhistoire à l'Actuel: Culture, Environnement et Anthropologie (PACEA), UMR 5199, 33400 Talence, France \\ ${ }^{4}$ Institut Pierre Simon Laplace, Pôle de Modélisation du Climat, Université Pierre et Marie Curie, 4 Place Jussieu, \\ Paris, France \\ ${ }^{5}$ LSCE/IPSL INSU, UMR 8212, CE Saclay, l’Orme des Merisiers, 91191 Gif-sur-Yvette Cedex, France
}

Correspondence to: M.-N. Woillez (marienoelle.woillez@gmail.com)

Received: 20 July 2013 - Published in Clim. Past Discuss.: 17 September 2013

Revised: 28 April 2014 - Accepted: 29 April 2014 - Published: 18 June 2014

\begin{abstract}
The relationships between climate, vegetation and fires are a major subject of investigation in the context of climate change. In southern Africa, fire is known to play a crucial role in the existence of grasslands and Mediterraneantype biomes. Microcharcoal-based reconstructions of past fire activity in that region have shown a tight correlation between grass-fueled fires and the precessional cycle, with maximum fire activity during maxima of the climatic precession index. These changes have been interpreted as the result of changes in fuel load in response to precipitation changes in eastern southern Africa. Here we use the general circulation model IPSL_CM5A (Institut Pierre Simon Laplace Climate Model version 5A) and the dynamic vegetation model LPJLMfire to investigate the response of climate, vegetation and fire activity to precession changes in southern Africa during marine isotopic stage 4 (74-59 kyr BP). We perform two climatic simulations, for a maximum and minimum of the precession index, and use a statistical downscaling method to increase the spatial resolution of the IPSL_CM5A outputs over southern Africa and perform high-resolution simulations of the vegetation and fire activity. Our results show an anticorrelation between the northern and southern African monsoons in response to precession changes. A decrease of the precession climatic index leads to a precipitation decrease in the
\end{abstract}

summer rainfall area of southern Africa. The drying of climate leads to a decrease of vegetation cover and fire activity. Our results are in qualitative agreement with data and confirm that fire activity in southern Africa during MIS4 is mainly driven by vegetation cover.

\section{Introduction}

The relationships between climate, ecosystems and fire are currently a major concern in the context of future climate change, as fire risk is expected to increase in several regions worldwide in response to both the rise in temperature and precipitation decrease (Liu et al., 2010). However the studies on this issue are usually based on predicted temperature and precipitation changes only (Liu et al., 2010). They do not take into account possible shifts in the ecosystems, which would change the amount of fuel available or its composition, such as the ratio from coarse fuels to fine fuels and the flammability of fuel components, which in turn will affect fire intensity and frequency (e.g., Daniau et al., 2007). This is particularly true for southern Africa, a land of contrasted climates and ecosystems. The western part receives less than $250 \mathrm{~mm} \mathrm{yr}^{-1}$ of precipitation and is occupied by desert and 
semi-desert biomes (Cowling et al., 1997). The eastern part is under the remote influence of the Intertropical Convergence Zone (ITCZ) and precipitation occurs during austral summer (November-March), when the ITCZ is at its southernmost position. In that region, annual precipitation amounts range from 500 to more than $1250 \mathrm{~mm} \mathrm{yr}^{-1}$ and allow the development of forests and savanna along the coast and grasslands in the more central regions (Cowling et al., 1997). The Cape region receives precipitation during the austral winter and the landscape is dominated by fynbos, a Mediterraneantype biome composed of evergreen shrubs. No fires occur in the desert and semi-desert regions due to the scarcity of fuel load, but the eastern grasslands and the southwestern fynbos are under the influence of an important fire activity, occurring mainly during the dry season, i.e., during austral winter and austral summer respectively (Archibald et al., 2010). Fire exclusion experiments performed in southern Africa suggest that fires play a crucial role in the existence of the grasslands and fynbos and that without fires climatic conditions would allow the development of forests in these regions (Westfall et al., 1983; Titshall et al., 2000). Simulations performed by Bond et al. (2003a, b) with a dynamic vegetation model including a fire module are consistent with these field experiments. In their simulations, forests cover the eastern part of southern Africa if fire disturbance is not taken into account.

Daniau et al. (2013) have analyzed microcharcoal concentrations in a marine sediment core off southwestern Africa and interpreted this marker as a record of past fire activity. The record, which covers the period from 170 to $30 \mathrm{kyr}$ BP (before present), exhibits a tight correlation between grassfueled fires and the precessional cycle, with maximum fire activity occurring during maxima of the climatic precession index ( $e \sin \omega$, with $e$ the eccentricity and $\omega$ the longitude of the perihelion), when the boreal winter solstice occurs near the perihelion. Daniau et al. (2013) hypothesized that the variations in fire activity reflect precipitation changes in the grassy regions of eastern southern Africa, i.e., in the summer rainfall area. The decrease in solar radiation during austral summer associated with a low precession index would weaken the ITCZ convection and bring less rainfall over southern Africa. A drier austral summer would lead to a decrease in the biomass of grassy vegetation, less fuel would be available during the dry season and fire activity would decrease. This study presents two interesting results: first, it suggests that in southern Africa a drier summer climate leads to a decrease rather than an increase in fire activity. Secondly it supports the link between precession and precipitation changes in southern Africa suggested by Partridge et al. (1997) and Kristen et al. (2007), based on lacustrine sediment analyses from northeastern southern Africa.

Similarly, different paleoclimatic records (e.g., Gasse, 2000; Wang et al., 2005) have shown the dominant role of precession in variations of the northern African and Indian monsoons during the Pleistocene, with increasing precipitation amounts for low values of the precession index (boreal winter solstice near the aphelion). The main forcing is the increase of summer insolation in the Northern Hemisphere during precession index minima, leading to warmer temperatures and lower pressures over the land masses and driving a more intense monsoonal flow. This interpretation has been confirmed by many numerical models for the Holocene (e.g., Braconnot et al., 2000; Braconnot and Marti, 2003; Ohgaito and Abe-Ouchi, 2007; Marzin and Braconnot, 2009b, a) and appears to remain a valid hypothesis even under glacial conditions (Masson et al., 2000). By contrast, only few empirical data on past environmental changes from the Southern Hemisphere are available and paleoclimatic records from southern Africa are particularly rare. Data from Partridge et al. (1997), Kristen et al. (2007), and Daniau et al. (2013) suggest an anticorrelation between the southern African monsoon and the northern African monsoon. To our knowledge no modeling study has yet been undertaken to investigate this hypothesis, neither has the link between precipitation, biomass burning and precession in southern Africa, in particular during glacial times, when the presence of Northern Hemisphere ice sheets and lower levels of greenhouse gases might have changed the sensitivity of the monsoons to precession changes.

Southern Africa is also a place of special interest regarding human evolution: the oldest symbolic designs, indicating the emergence of modern human behavior, date to marine isotope stage 4 (MIS4, $74-59 \mathrm{kyr} \mathrm{BP}$ ) (Jacobs et al., 2008; Henshilwood et al., 2002, 2009; d'Errico and Henshilwood, 2007). Reconstructing climate, vegetation and fire activity evolution in southern Africa, through the study of marine and terrestrial archives or paleoclimatic simulations, is therefore an important task to address the aforementioned climatic, ecological and archeological questions.

Here we investigate the role of precession changes on the southern African climate, vegetation and fire activity during MIS4 through numerical modeling. We use the AtmosphereOcean General Circulation Model (AOGCM) IPSL_CM5A (Institut Pierre Simon Laplace Climate Model version 5A) (Dufresne et al., 2013) to perform simulations at the beginning and end of MIS4, which correspond to a maximum and minimum of the precession index respectively. Vegetation and fire changes during these two periods are investigated with the dynamic vegetation model LPJ-LMfire (Pfeiffer et al., 2013). Fire occurrence depends on environmental conditions at a local scale (moisture, vegetation type, fuel amount and type). Using the relatively coarse outputs from the GCM to force LPJ-LMfire would lead to unrealistic simulations of burnt areas. Therefore we use a statistical downscaling method to increase the spatial resolution of the GCM outputs. The high-resolution climatic fields we obtain are used to force LPJ-LMfire and simulate fire activity at a local scale. 


\section{Methods}

\subsection{Climate model and boundary conditions}

We use the IPSL AOGCM in its version IPSL_CM5A (Dufresne et al., 2013). The atmosphere is simulated with the LMDZ model (Hourdin et al., 2006), coupled to the ocean model OPA8/NEMO (Madec et al., 1998), through the OASIS coupler (Valcke, 2006). The atmosphere is simulated on a regular grid with 96 pixels $\times 95$ pixels in longitude $\times$ latitude at the global scale (i.e., a spatial resolution of about $3.75^{\circ} \times 1.9^{\circ}$ ) and 39 altitude levels, which allows the simulation of the stratosphere dynamics. The global ocean is simulated on an irregular horizontal grid of 182 points $\times 142$ points and 31 depth levels. Sea-ice is dynamically simulated with the LIM2 model (Fichefet and Morales-Maqueda, 1997, 1999). The land-surface types and resulting atmosphere-surface exchanges are described by the ORCHIDEE model (Krinner et al., 2005), at the same spatial resolution as for the atmosphere. In this version of IPSL_CM5A the vegetation is fixed according to its presentday distribution, including agriculture, but phenology is interactively computed, depending on the climatic conditions. The performances of this new version of the IPSL model for past climates (mid-Holocene and last glacial maximum) have been described in Kageyama et al. (2013a, b).

We perform two simulations of the MIS4 climate, at $72 \mathrm{kyr}$ and $60 \mathrm{kyr} \mathrm{BP}$, corresponding to a maximum and minimum of the precession index respectively and hereafter labeled MIS4_max and MIS4_min. The boundary conditions are set as follows: for both simulations we use the ICE6G_Interim ice-sheet reconstructions (Argus and Peltier, 2010) for $16 \mathrm{kyr} B P$ (unpublished data) as an analogue for the MIS4 ice sheets, as both periods exhibit approximately the same sea-level change (about $70 \mathrm{~m}$ lower than present day, Waelbroeck et al., 2002). The land-sea distribution and topography are modified accordingly to this lower sea level. The greenhouse gas concentrations are fixed according to the ice-core records (Petit et al., 1999; Spahni et al., 2005) for $72 \mathrm{kyr}$ and $60 \mathrm{kyr}$ BP (see Table 1) and the orbital parameters are taken from Laskar et al. (2004) (Table 1 and Fig. S1 in the Supplement).

The orbital configuration for MIS4_max is relatively close to present day, with the boreal winter solstice near the perihelion. The configuration is opposite in MIS4_min, with the boreal winter solstice occurring when the Earth is close to the aphelion (Fig. S1 in the Supplement). In the Northern Hemisphere, the precession decrease between the beginning (MIS4_max) and end (MIS4_min) of MIS4 correspond to an increase in solar radiation during boreal summer, with a maximum in July (Fig. 1) and to a decrease during boreal winter. In the Southern Hemisphere a positive anomaly occurs during late austral winter and spring (from July to November), with a maximum anomaly in October south of $60^{\circ} \mathrm{S}$ (Fig. 1).

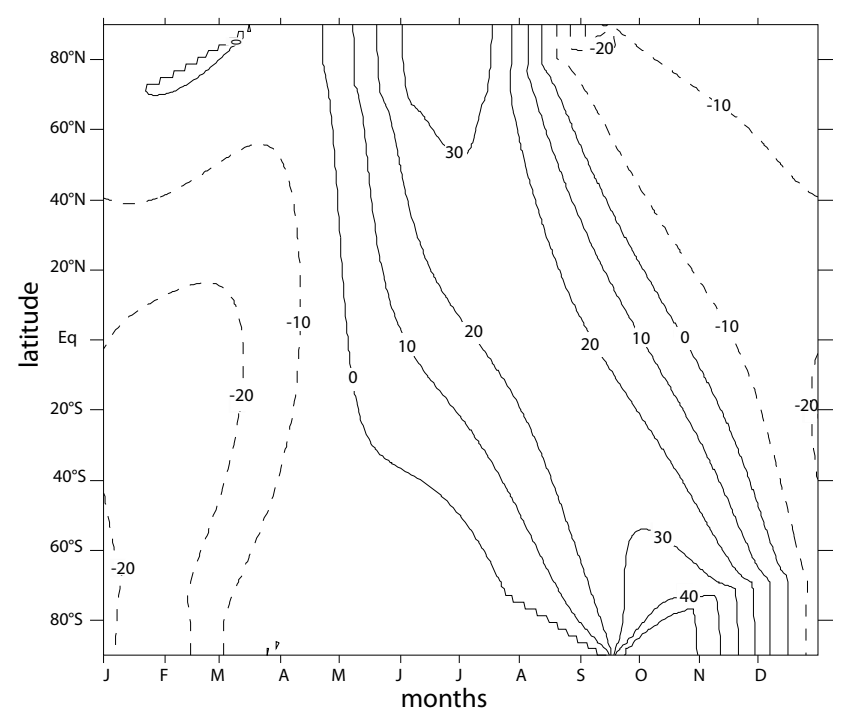

Figure 1. Anomalies (MIS4_min-MIS4_max) in incoming solar radiation at the top of the atmosphere $\left(\mathrm{W} \mathrm{m}^{-2}\right)$ averaged over the longitude and plotted as a function of months. The figure has been plotted based on the daily insolation values.

Both simulations are run about $600 \mathrm{yr}$, until the surface climatic variables are at equilibrium, and we analyze averages over the last $60 \mathrm{yr}$ of each simulation.

\subsection{The vegetation and fire model LPJ-LMfire}

\subsubsection{Model description}

To simulate the vegetation and fire activity in southern Africa, we use the process-based dynamic global vegetation model (DGVM) LPJ-LMfire (Pfeiffer et al., 2013), a new version of the Lund-Potsdam-Jena DGVM (LPJ, Sitch et al., 2003) that includes an improved version of the SPITFIRE (SPread and InTensity of FIRE) fire module (Thonicke et al., 2010). The model dynamically simulates nine different plant functional types (PFTs) (seven woody PFTs, C3 and $\mathrm{C} 4$ grasses), as well as the productivity and the terrestrial carbon cycle, in response to the climatic forcings, insolation, atmospheric $\mathrm{CO}_{2}$ level and competition between the PFTs. The vegetation cover is described in fractions of grid cells covered by the different PFTs, which can coexist on the same grid cell. The fractional coverage of a given PFT depends on both the productivity and the individual density, which vary independently. The spatial resolution is the same as the climatic forcings chosen by user, $0.16^{\circ}$ in our case (see Sect. 2.2.2), and agricultural land use is not taken into account.

The vegetation simulated by the DGVM provides information about the fuel type and fuel load to the fire module. The fire module in turn computes fire occurrence, spread and impact on vegetation, depending on fuel information, meteorological conditions and ignition sources. Lightning strikes 
Table 1. Earth's orbital parameters and greenhouse concentration values for the two MIS4 IPSL_CM5A simulations. $\omega$ stands for the longitude of the perihelion and $e$ for the eccentricity.

\begin{tabular}{lccccccc}
\hline Simulation name & eccentricity & obliquity & $\begin{array}{c}\omega \\
-180\end{array}$ & $\begin{array}{c}\text { precession } \\
\text { index }(e \sin \omega)\end{array}$ & $\begin{array}{c}\mathrm{CO}_{2} \\
(\mathrm{ppm})\end{array}$ & $\begin{array}{c}\mathrm{CH}_{4} \\
(\mathrm{ppb})\end{array}$ & $\begin{array}{c}\mathrm{N}_{2} \mathrm{O} \\
(\mathrm{ppb})\end{array}$ \\
\hline MIS4_max (-72 kyr) & 0.02434 & 22.3907 & 80.09 & 0.01496 & 230 & 450 & 230 \\
MIS4_min (-60 kyr) & 0.01846 & 23.2329 & 266.65 & -0.01785 & 200 & 426 & 230 \\
\hline
\end{tabular}

are the only source of ignition taken into account in our simulations.

We run LPJ-LMfire off-line, i.e., there is no vegetation feedback on climate. To drive the model we need information on climate, soils, topography and atmospheric $\mathrm{CO}_{2}$ concentrations. The required climatic variables are monthly means of air temperature, the range of the diurnal cycle, precipitation, the number of wet days, cloudiness, wind speed and lightning strike frequency, with interannual variability. A weather generator implemented in the model produces daily values from the monthly data.

\subsubsection{Forcing fields}

To perform vegetation and fire simulations at high resolution, we use the IPSL_CM5A outputs downscaled (see Sect. 2.3) or interpolated to a spatial resolution of $0.16^{\circ}$ as climatic forcings. This resolution corresponds to the spatial resolution of the Climate Research Unit data (New et al., 2002) used in the downscaling method (Sect. 2.3). As mentioned previously LPJ-LMfire requires forcings with interannual variability. Since the downscaling procedure provides only a mean climatology we use an anomaly procedure to build the forcing fields:

- We average the detrended version of a 20th century reanalysis climatology constructed by Pfeiffer et al. (2013), and increase its initial spatial resolution $\left(0.5^{\circ}\right)$ to $0.16^{\circ}$ through a bilinear interpolation. We thus obtain a high-resolution mean present-day climate.

- We compute the anomaly between this mean presentday climate and the high-resolution climatology from the IPSL_CM5A simulation.

- We add the anomaly to the detrended version of the 20th century reanalysis climatology. We therefore make the assumption that there has been no change in interannual variability, which is the best approach we could follow here given the available data. It would be interesting to test this hypothesis with high-resolution regional climate models in future work.

Lightning strike frequency is not simulated in IPSL_CM5A. For this variable we keep the time series constructed by Pfeiffer et al. (2013) based on a modern data set (Christian et al., 2003) and on the convective available potential energy anomalies from the 20th century reanalysis project (Compo et al., 2011) to account for interannual variability. Similarly, soil types are taken from the standard driver data set of Pfeiffer et al. (2013). Lightning and soil variables are simply bilinearly interpolated to $0.16^{\circ}$.

We perform three simulations of the southern African vegetation: a control simulation using the outputs of a present-day simulation of IPSL_CM5A and two MIS4 simulations, using the outputs of the MIS4_max and MIS4_min IPSL_CM5A simulations. The atmospheric $\mathrm{CO}_{2}$ level is fixed at 310, 230 and $200 \mathrm{ppm}$ (parts per million) respectively. For MIS4 simulations, new land points appear along the coastal edges, due to the glacial sea-level reduction. For all variables, the standard input data of Pfeiffer et al. (2013) are extrapolated on these new points using the nearest continental neighbor.

Several forcing parameters change between the MIS4_min and MIS4_max LPJ-LMfire simulations: climate, insolation and atmospheric $\mathrm{CO}_{2}$, which is known to impact vegetation through its impact on photosynthesis and respiration rates as well as on the plant's water-use efficiency (e.g., Jolly and Haxeltine, 1997; Cowling and Sykes, 1999; Harrison and Prentice, 2003; Prentice and Harrison, 2009; Woillez et al., 2011). To investigate the relative impact of these forcing factors we perform four sensitivity experiments, hereafter labeled TEST_PRECIP, TEST_TEMP, TEST_CO2 and TEST_INSOL.

In TEST_PRECIP (resp. TEST_TEMP), we force LPJLMfire with the MIS4_max conditions, except for precipitation and the number of wet days (resp. the air temperature and the amplitude of the diurnal cycle) for which we take the values from MIS4_min. Thus, we isolate the impact of the change in precipitation (resp. temperature) alone when precession decreases. In TEST_CO2, LPJ-LMfire is forced with the MIS4_max climate, but with a $\mathrm{CO}_{2}$ value of $200 \mathrm{ppm}$ to isolate the impact of the $\mathrm{CO}_{2}$ decrease between the beginning and end of MIS4. And finally, in TEST_insol we force LPJ-LMfire with the climate of MIS4_max but impose the orbital parameters of MIS4_min: this run tests the impact of solar insolation change alone on photosynthesis and thus on vegetation productivity.

For all simulations, the model is spun up for $1080 \mathrm{yr}$, to make sure that the vegetation is at equilibrium with the climatic forcings. The analysis of the outputs are performed on averages over the last $60 \mathrm{yr}$ of simulation. 
Table 2. List of the predictors selected to perform the downscaling of monthly temperature and precipitation variables over southern Africa. The predictors "temperature", "relative humidity", "amplitude of the diurnal cycle", "precipitation" and "wind" are taken from the IPSL_CM5A simulation and interpolated to $0.16^{\circ}$. The diffusive continentality index corresponds to the shortest distance to the ocean; the advective continentality index depends on both the wind simulated in the GCM and the distance to the ocean. See Levavasseur et al. (2011) for a complete description of the construction of these two predictors.

\begin{tabular}{|c|c|c|}
\hline Predictand & Predictors & $\begin{array}{l}\text { Explained } \\
\% \text { of variance }\end{array}$ \\
\hline Air temperature & $\begin{array}{l}\text { Temperature, topography, } \\
\text { diffusive continentality index }\end{array}$ & 94.7 \\
\hline $\begin{array}{l}\text { Amplitude of the } \\
\text { diurnal cycle }\end{array}$ & $\begin{array}{l}\text { Temperature, topography, } \\
\text { relative humidity, amplitude of } \\
\text { the diurnal cycle, diffusive } \\
\text { continentality index }\end{array}$ & 82.1 \\
\hline Precipitation & $\begin{array}{l}\text { Temperature, advective and diffu- } \\
\text { sive continentality indexes, } \\
\text { precipitation, wind, topography }\end{array}$ & 58.5 \\
\hline $\begin{array}{l}\text { Number of wet } \\
\text { days }\end{array}$ & $\begin{array}{l}\text { Temperature, advective and } \\
\text { diffusive continentality indexes, } \\
\text { precipitation, wind, topography }\end{array}$ & 88.5 \\
\hline
\end{tabular}

\subsection{Statistical downscaling}

To increase the spatial resolution of the AOGCM outputs required to drive LPJ-LMfire at high resolution over southern Africa, we chose to apply a downscaling method and use a generalized additive model (GAM). The advantages of a GAM compared to other downscaling procedures has been shown by Wilby et al. (1998). Here we follow the approach developed by Vrac et al. (2007) for western Europe.

The downscaling procedure has been performed using the statistical programming environment $\mathrm{R}$ (R Development Core Team, 2009) and its "mgcv" package (Wood, 2006). The method has been developed and evaluated for the downscaling of air temperature and precipitation (Vrac et al., 2007; Martin et al., 2011; Levavasseur et al., 2011). Here we also apply it for the downscaling of the diurnal-cycle amplitude and number of wet days, which by nature are expected to behave similar to temperature and precipitation respectively. The downscaling method has not been tested for cloudiness and wind speed, so these two variables were simply bilinearly interpolated to the desired $0.16^{\circ}$ spatial resolution.

The GAM builds statistical relationships between localscale observations (called predictand) and large-scale variables (called predictors, generally from fields of climate models). The expectation of the explained variable $Y$ (the predictand) is computed by a sum of nonlinear functions, defined as cubic splines in our case, conditionally on the predictors $X$ (Hastie and Tibshirani, 1990):

$E\left(Y_{i} \mid X_{n, n=1 \ldots k}\right)=\beta_{0}+\sum_{n=1}^{k} f_{n}\left(X_{i, n}\right)$, a) IPSL_CM5A Outputs
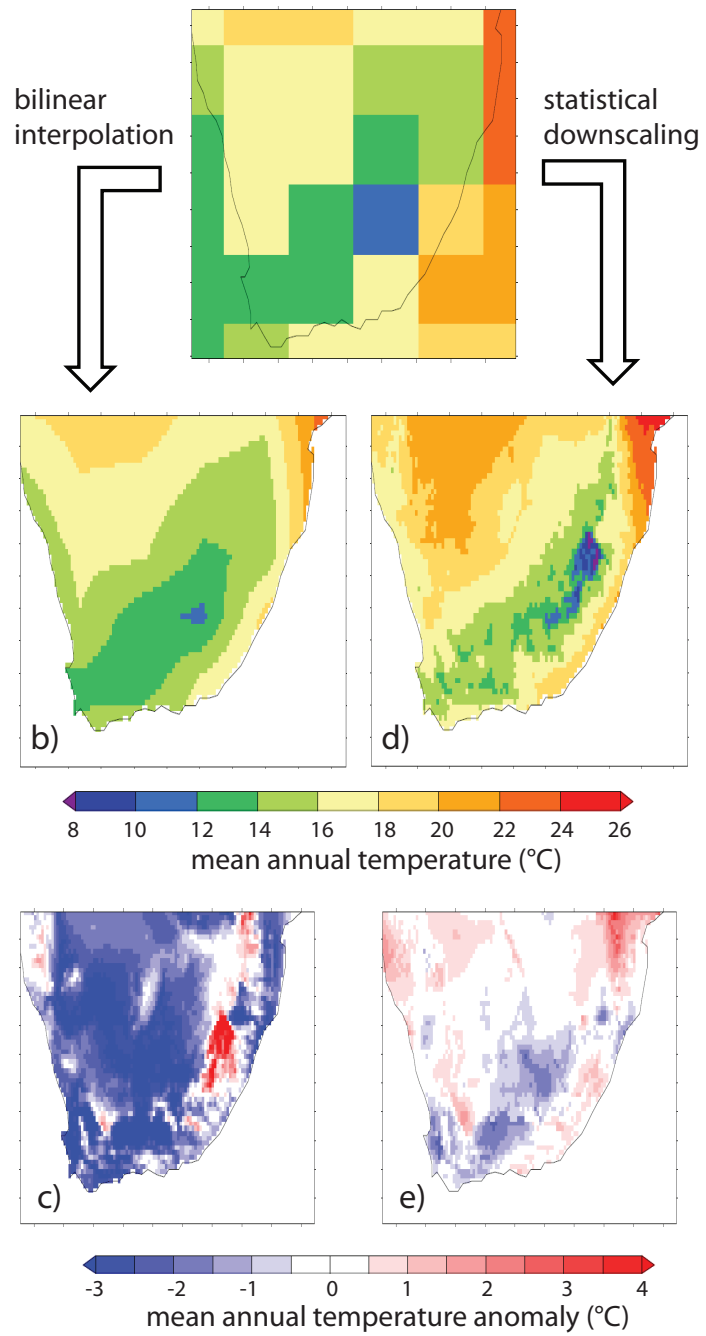

Figure 2. (a) Mean Annual temperature for present day simulated by IPSL_CM5A over southern Africa (average over the years 19601990 from a 20th century simulation). Mean annual temperature simulated by IPSL_CM5A for present day with a spatial resolution increased to $0.16^{\circ}$ through a bilinear interpolation (b) and difference with the CRU data (IPSL_CM5A - CRU) (c). Mean Annual temperature simulated by IPSL_CM5A for present day with a spatial resolution increased to $0.16^{\circ}$ through statistical downscaling (d) and difference with the CRU data (IPSL_CM5A - CRU) (e).

where $\beta_{0}$ is the intercept, $k$ the number of predictors and $i$ the grid cell.

Spline functions are piecewise third-order polynomial functions, evaluated at $4 \mathrm{kn}$. Each function has at most $12 \mathrm{pa}-$ rameters. Such a model has both a great flexibility and a (relatively) limited number of parameters to compute (see Vrac et al., 2007 for more details).

To calibrate the GAM (i.e., to build the splines) we use the high-resolution gridded climatologies from the Climate Research Unit (CRU) database (New et al., 2002) as 

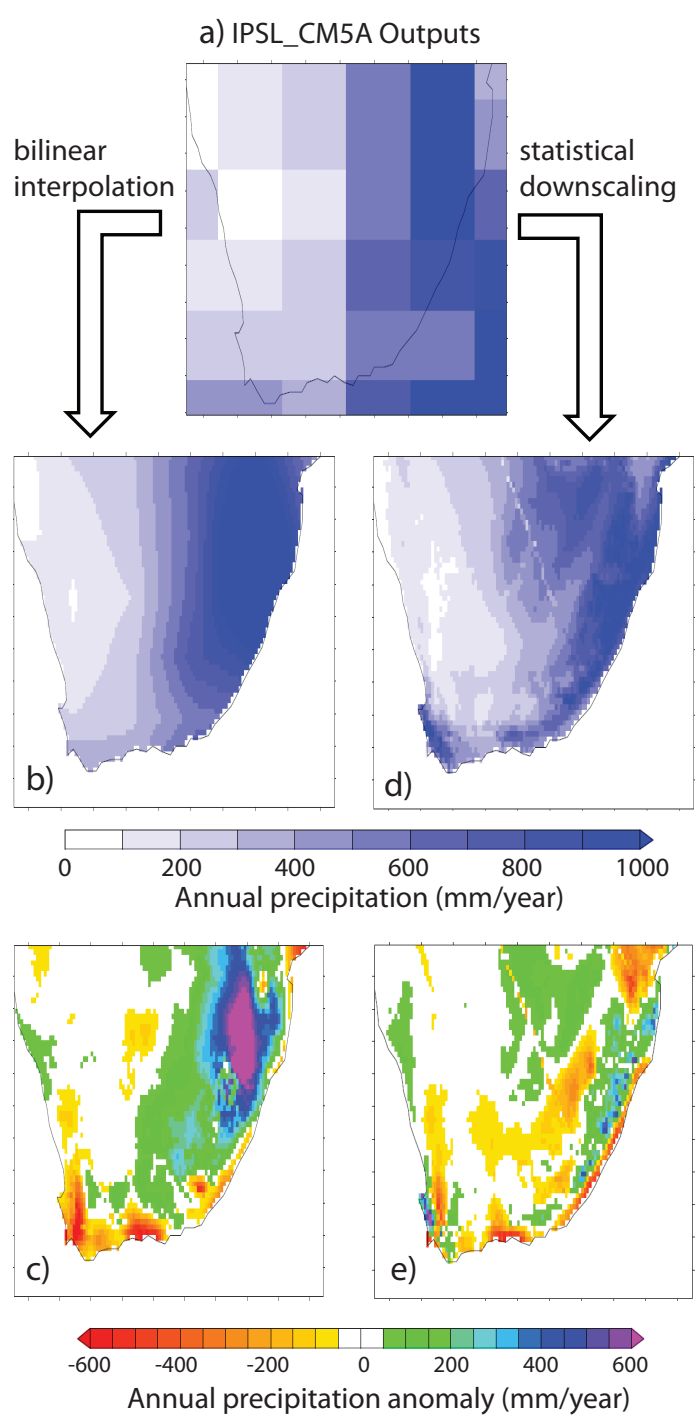

Figure 3. (a) Annual precipitation $\left(\mathrm{mm} \mathrm{yr}^{-1}\right)$ for present day simulated by IPSL_CM5A over southern Africa (average over the years 1960-1990 from a 20th century simulation). Annual precipitation simulated by IPSL_CM5A for present day with a spatial resolution increased to $0.16^{\circ}$ through a bilinear interpolation (b) and difference with the CRU data (IPSL_CM5A - CRU) (c). Annual precipitation simulated by IPSL_CM5A for present day with a spatial resolution increased to $0.16^{\circ}$ through statistical downscaling (d) and difference with the CRU data (IPSL_CM5A - CRU) (e).

predictands. For each grid-point, each data set consists of 12 monthly means (average over the period 1961-1990) at a regular spatial resolution of $0.16^{\circ}$ in latitude and longitude, corresponding to our downscaling resolution. To use the GAM as in Eq. (1), the distribution family of the explained variable is assumed to be Gaussian. Although temperature data classically satisfy this normality assumption, precipitation values have to be log-transformed before the calibration step (Cheng and Qi, 2002).
The predictors may be divided into two groups: the "physical" predictors and the "geographical" ones. The "physical" predictors are directly extracted from a 20th century IPSL_CM5A simulation (years 1961-1990) and depend on climate dynamics. The "geographical" predictors include geographical information such as topography and distance to the ocean. All the predictors must have the same spatial resolution as the predictands. Therefore, the IPSL_CM5A outputs used as predictors are bilinearly interpolated to $0.16^{\circ}$.

The statistical relationships are established only for a given region and cannot be applied to another. Therefore, we have performed different tests to select the appropriate combinations of predictors for southern Africa, which differ from the selection of Vrac et al. (2007) for Europe. The "optimal" predictors set is selected according to the Bayesian information criterion (BIC, Schwartz, 1978) as described by Vrac et al. (2007). The BIC allows selecting a statistical model (and the associated predictors) by balancing the risk of overfitting.

To be evaluated in fair conditions, the GAM requires independent samples between the calibration and projection steps. This condition is not satisfied for the present day since we use the same IPSL_CM5A simulation for both steps. Therefore, following Levavasseur et al. (2011), we use a "cross-validation" procedure and do the calibration on 11 months and the projection on the remaining month. With a rotation of this month we are thus able to perform the projection step for any month based on an independent calibration data set.

To perform the downscaling for MIS4, we use the splines built for present day and project with the MIS4 predictors (for both MIS4_max and MIS4_min experiments). If the predictors values for the MIS4 simulation are outside the calibration range, the spline is simply linearly extrapolated to cover the whole range of the new values.

\section{Results and discussion}

\subsection{Downscaling results for present-day southern African climate}

Our best predictors' combinations to downscale independently air temperature, diurnal-cycle amplitude, precipitation and number of wet days are listed in Table 2 with their respective percentage of explained variance (i.e., the percentage of observed variance explained by a given set of explanatory variables, Saporta, 1990):

$\%$ of variance explained $=\frac{\sum_{i}\left(y_{i}^{*}-\bar{y}\right)^{2}}{\sum_{i}\left(y_{i}-\bar{y}\right)^{2}} \times 100$,

where $y_{i}^{*}$ is the GAM-predicted value, $y_{i}$ the observed value, and $\bar{y}$ the observed mean.

As "physical" predictors we use air temperature at the surface, precipitation, relative humidity, diurnal-cycle amplitude 
a) Observed modern biomes

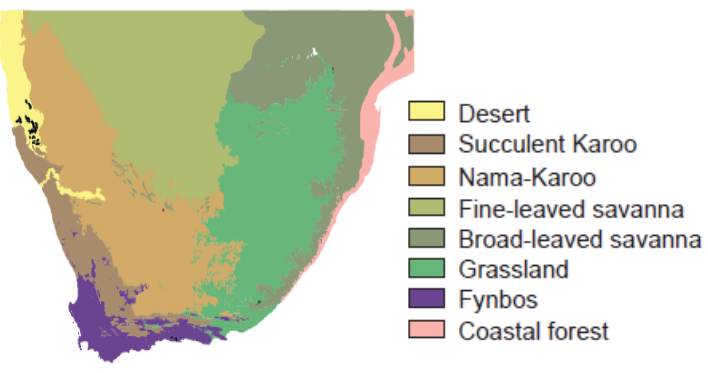

c) LPJ-LMfire outputs

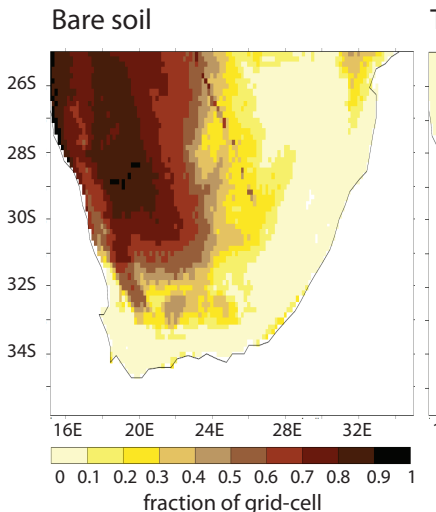

b) Observed tree cover

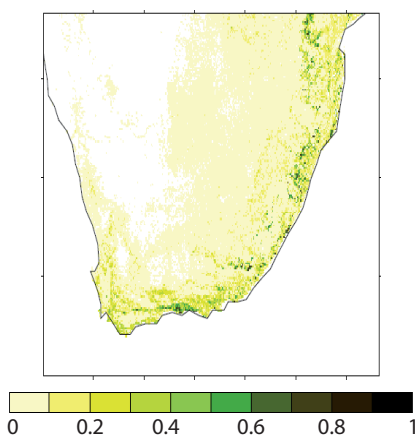

Grasses

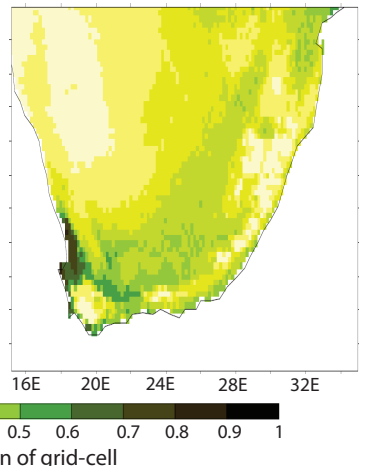

Figure 4. (a) Modern biomes of southern Africa (Scholes, 1997; Mucina et al., 2007). (b) Observed tree cover from remote sensing data, average over years 2001-2010 (MODIS database, Townsend et al., 2011). Grid cells with fractions $<1 \%$ are in white. (c) Vegetation cover (bare soil, trees and grass fractions) simulated with LPJ-LMfire forced off-line by the outputs of a present-day IPSL_CM5A simulation downscaled to $0.16^{\circ}$.

and wind speed at $10 \mathrm{~m}$. The "geographical" predictors are the topography and two continentality indexes. To account for the effect of local elevation on climate we use the high-resolution gridded topography ETOPO2 from the National Geophysical Data Center (NGDC, Amante and Eakins, 2008). For MIS4 we have added $+70 \mathrm{~m}$ to this topography, to account for the reduced sea level compared to present day. The first continentality index is the "diffusive" continentality (DCO), which represents the shortest distance to the ocean (e.g., $0 \%$ at the ocean's edge and $100 \%$ very remote from any ocean, corresponding to a purely continental air parcel; for southern Africa DCO reaches $100 \%$ about $300 \mathrm{~km}$ from the ocean). The second continentality index is the "advective" continentality (ACO). ACO is similar to DCO albeit being modulated by the large-scale wind intensities and directions simulated with IPSL_CM5A and represents an index of the continentalization of air masses. For more details about ACO and DCO the reader is referred to Levavasseur et al. (2011).

Figures 2 and 3 illustrate the improvement of the presentday IPSL_CM5A temperature and precipitation outputs through the downscaling. When the mean annual temperature simulated with IPSL_CM5A for present day is simply inter- polated to $0.16^{\circ}$ (Fig. 2b) the values are systematically lower than the CRU data (Fig. 2c), except in the eastern mountains, where the orographic effect is not correctly captured and the temperature is overestimated by $3-4^{\circ} \mathrm{C}$. The downscaling method (Fig. 2c) corrects this cool bias and better captures the temperature pattern on elevated regions (Fig. 2d). We obtain a very high percentage of variance explained for this variable (about $95 \%$, see Table 2). We also obtain satisfactory results for the amplitude of the diurnal cycle, with about $82 \%$ of the variance explained (Table 2).

The comparison between the interpolated annual precipitation simulated by IPSL_CM5A and the CRU data (Fig. 3b, c) show that the AOGCM strongly overestimates precipitation in the summer rainfall area (positive anomaly above $600 \mathrm{~mm} \mathrm{yr}^{-1}$ ) and fails to simulate the austral winter precipitation in the southwest. The precipitation pattern obtained after downscaling (Fig. 3d, e) reduces both biases. The percentage of variance explained is however only $58.5 \%$ (Table 2). This relatively low percentage is in the range of the explained variance values obtained by Martin et al. (2011) for Europe. Capturing the precipitation pattern at a small spatial scale remains a challenge, given the spatially variable nature 


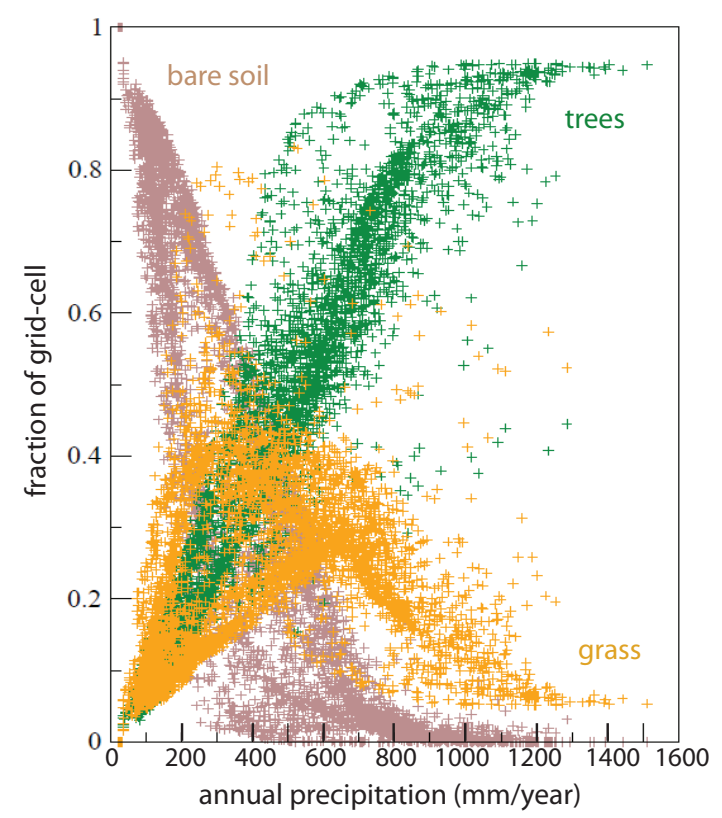

Figure 5. Vegetation cover simulated for present day with LPJLMfire over southern Africa: fraction of a grid cell occupied by bare soil (brown), trees (green) and grass (yellow) vs. the total annual precipitation on the same grid cell.

of precipitation, thus we did not expect to reach a higher percentage of explained variance.

The downscaling procedure assumes that the statistical relationships established for present-day climate are stationary in time and remain valid for different periods. This assumption may be questionable in a paleoclimatic context (Vrac et al., 2007), particularly if the values of the predictors are outside the calibration range. In our case, most of the predictors' values for MIS4_max and MIS4_min are still within the range of calibration, thus bringing confidence to the validity of the statistical relationships for that period. Some of the MIS4 monthly temperature values simulated by IPSL_CM5A are lower than the calibration values by a few degrees Celsius, corresponding to the austral winter temperatures in the center of southern Africa, but the splines constructed by the GAM for this predictor are roughly linear and a linear extrapolation should not lead to unrealistic projections (see Fig. S2 in the Supplement). We are therefore confident that the method can reasonably be applied for the downscaling of the MIS4 climate over southern Africa.

\subsection{Simulation of present-day vegetation and fire activity over southern Africa}

\subsubsection{Vegetation}

The different biomes currently present in southern Africa have been initially described and classified by White (1983). This first classification has been revisited by Rutherford
(1997), Scholes (1997), and Mucina et al. (2007). Urrego et al. (2014) combine the classification of Scholes (1997) and Mucina et al. (2007) and distinguish eight different biomes: desert, Nama Karoo and Succulent Karoo (semi-desert) in the western and central regions, fynbos (Mediterranean hardleaf scrubs) in the southern coastal regions, grasslands in the east, broad-leaved savanna in the north, fine-leaved savanna in the north and central west, and forest in the eastern coastal regions (Fig. 4a). Remote sensing data (MODIS database, Fig. 4b), (Townsend et al., 2011) show that tree fractions are above $20 \%$ only along the coastal regions of the Indian Ocean, corresponding to the biome coastal forest and to parts of the broad-leaved savanna and fynbos. These forested regions appear rather fragmented, which is probably partly due to anthropogenic impacts: most tree fractions values range between 20 and $30 \%$ and values above $50 \%$ are limited to small patches. In regions of fine-leaved savanna, grasslands and parts of the karoo, tree fractions are below $10 \%$. Trees are absent in the most desertic regions in the west.

In order to evaluate the performance of LPJ-LMfire for present day, we compare qualitatively the vegetation simulated in the control present-day run, given as fractions of a grid cell occupied by bare soil, trees and grass (Fig. 4c) to the modern biome distribution (Fig. 4a) and to the observed tree fractions (Fig. 4b).

LPJ-LMfire simulates high bare-ground fractions in the northwest, above $50 \%$ west of $24^{\circ} \mathrm{E}$ and north of $32^{\circ} \mathrm{S}$ (Fig. 4c), corresponding roughly to the desert and karoo regions (Fig. 4a). The center of the sub-continent is occupied by a mixture of bare soil, grass and trees. High grass fractions are simulated in the south and southwest. On the eastern side and southern coast, including the Cape region, the model simulates forest fractions above $50 \%$ (Fig. 4c), composed mainly of temperate woody PFTs.

The distribution of the simulated vegetation strongly depends on the annual precipitation (Fig. 5). The fraction of bare soil (trees) decreases (increases) somewhat linearly when annual precipitation increases (decreases). The grass fractions globally increase with annual precipitation between 0 and $600 \mathrm{~mm} \mathrm{yr}^{-1}$, decrease for wetter conditions and are replaced by trees, which are more competitive. We can distinguish two peaks in the grass fractions around annual precipitation values of 300 and $600 \mathrm{~mm} \mathrm{yr}^{-1}$. The first peak corresponds to the hinterland of the Cape region, where precipitation occurs during the austral winter, and the second one reflects the gradual increase and decrease of grass fractions from the west to the east of southern Africa (Fig. 4a).

The presence of forests in the Cape region disagrees with observations (Fig. 4b), since the region is actually covered by the mediterranean-like scrub fynbos (Fig. 4a). This bias was expected since LPJ-LMfire does not simulate shrubs. The model also overestimates the westwards expansion of the eastern coastal forests, as well as their fractional coverage $(>70 \%)$. This bias is also present when LPJ-LMfire is forced with the original data set of Pfeiffer et al. (2013), 
a)

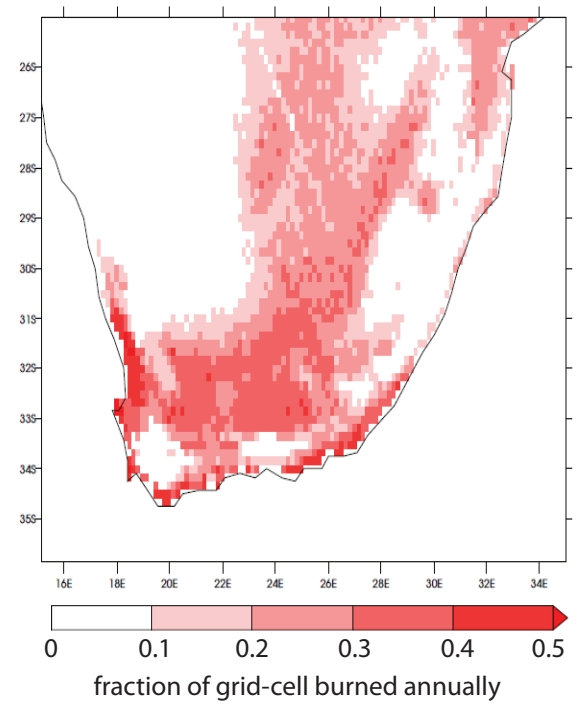

b)

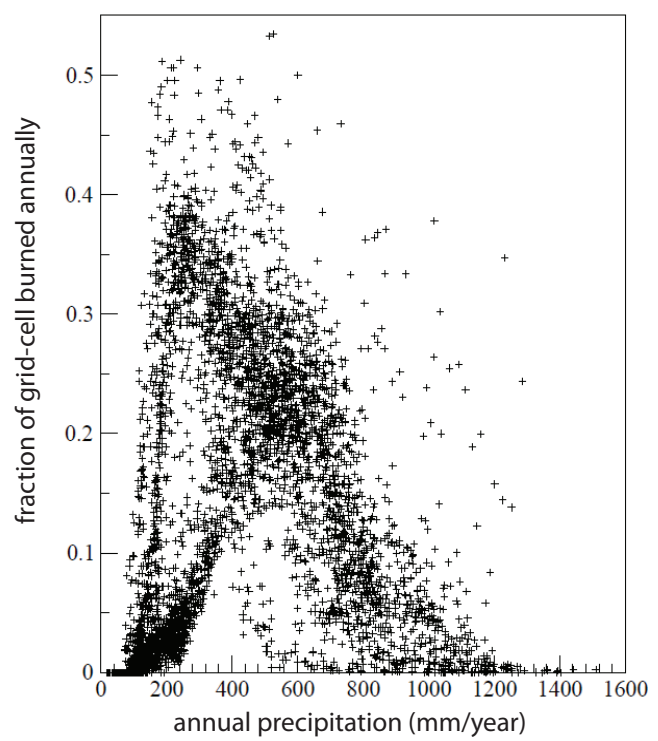

Figure 6. Present-day simulation of fire activity over southern Africa with LPJ-LMfire. (a) Fraction of a grid cell burned annually. (a) Annual fraction of a grid cell burned vs. total annual precipitation on the same grid cell $\left(\mathrm{mm} \mathrm{yr}^{-1}\right)$.

based on observations and reanalyses (data not shown), and therefore can be attributed to the DGVM itself rather than to biases in the climatic forcings from IPSL_CM5A.

The overestimation of trees and underestimation of grasses compared to observations could be due either to intrinsic biases of the DGVM, or to the anthropogenic influence on the modern southern African vegetation. The diverse parameterizations used in the simulation of processes governing vegetation dynamics or in the fire module may not be optimal for southern Africa, especially at high spatial resolution. In a similar simulation performed over Europe (data not shown) the model results show the same type of biases and overestimates forests in the Mediterranean region, which suggests that the impact of a large amplitude in the hydrological seasonal cycle on vegetation is not adequately simulated in the model. The impact of fire on tree development, which has been suggested to be a determining factor in southern Africa (Westfall et al., 1983; Titshall et al., 2000; Bond et al., 2003a, b), may also be underestimated. The improvement of the model calibration may be possible, but requires further tests and comparisons with observation data at a local scale from regions without current anthropogenic impact, such as national parks.

Indeed, the model simulates the potential vegetation, i.e., without any anthropogenic disturbance such as agriculture, farming, impact on the fire regime through anthropogenic ignition or fire suppression, or spreading of alien plants (for more details on human impact on fire regimes in Africa, see Archibald et al. $(2009,2012)$. The modern landscape could be at least partly the result of human activities (Pfeiffer et al., 2013). This hypothesis is supported by pollen data from the marine core MD96-2048, off the coast of eastern southern Africa (Dupont, 2011), which show higher percentages of tree pollen during the last interglacial, when human impact was likely negligible.

\subsubsection{Fire}

For present day, LPJ-LMfire simulates fires mainly in the center of southern Africa, between 23 and $27^{\circ} \mathrm{E}$, and in the south, between $31-33^{\circ} \mathrm{S}$. In these two regions, annual burned area fractions are around $20-30$ and $30-40 \%$ respectively (Fig. 6a). In other words, fires occur outside the desert region on the western side, where fuel load is too small to sustain fires, and outside of the regions where humidity and tree fractions are high (Fig. 4c).

Figure $6 \mathrm{~b}$ shows the annual fraction of a burned grid cell plotted against annual precipitation. The model simulates two peaks in fire activity, around 300 and $600 \mathrm{~mm} \mathrm{yr}^{-1}$, corresponding to the grid cells with the maximum fractions of grass (Fig. 5b). For precipitation above $600 \mathrm{~mm} \mathrm{yr}^{-1}$, the burned fractions steeply decrease, reflecting the lower fire activity for wetter conditions and high tree fractions. Below $300 \mathrm{~mm} \mathrm{yr}^{-1}$, fire activity also decreases, following the decrease in available fuel load.

The maximum burned area fractions simulated with LPJLMfire are about three to four times higher than modern observations of fire activity in southern Africa: for the period 1997-2011, the average annual burned area fractions are below $5 \%$ (Giglio et al. (2010); http://globalfiredata.org; data for southern Africa shown on Fig. S3 in the Supplement). 
a) MIS4_min-MIS4_max JJA
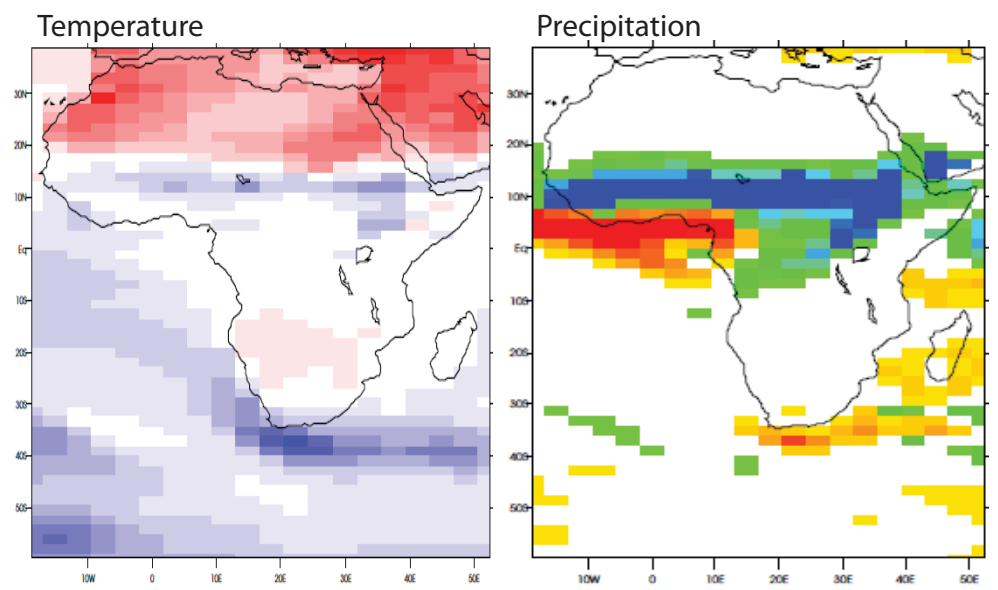

b) MIS4_min - MIS4max DJF
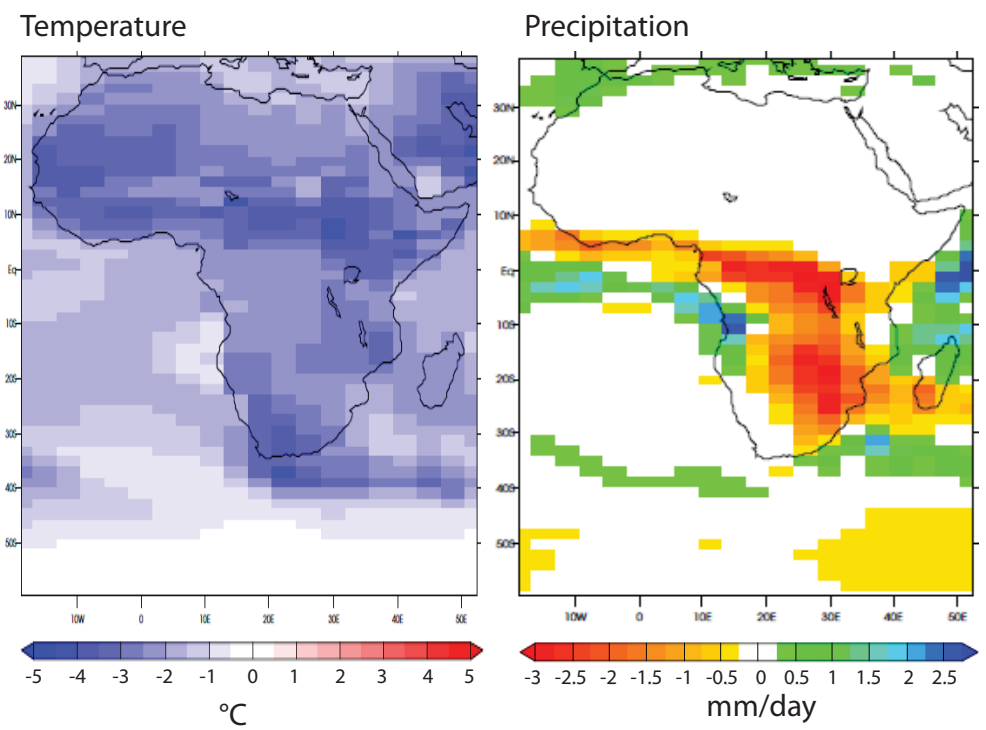

Figure 7. Difference in mean temperature $\left({ }^{\circ} \mathrm{C}\right)$ and mean precipitation $\left(\mathrm{mm}^{-1} \mathrm{y}^{-1}\right)$ simulated with IPSL_CM5A between the beginning and end of MIS4 (MIS4_min-MIS4_max). (a) Average for the boreal summer months (June-August); (b) average for the boreal winter months (December-February).

Our results are in agreement with Pfeiffer et al. (2013), i.e., without agricultural land cover. If agriculture is taken into account and lightning-caused fires are excluded from the cultivated areas, results are in good agreement with observations (Pfeiffer et al., 2013), which suggests a strong influence of human activity through agriculture on the modern fire regime of southern Africa. The overestimation of annual burned fractions in southern Africa in our simulations can thus be attributed to the absence of agricultural land use and does not prevent the analysis of the response of the fire regime to paleoclimatic changes.

\subsection{Climate, vegetation and fire response to precession changes for MIS4 conditions}

\subsubsection{Climate}

Here we focus on the temperature and precipitation changes when precession decreases for MIS4 boundary conditions (MIS4_min-MIS4_max) over Africa. The mean features of the temperature and precipitation anomalies at global scale simulated in MIS4_max compared to present day can be found in the Supplement (Fig. S4 in the Supplement). Here we focus on the temperature and precipitation changes when precession decreases for MIS4 boundary conditions (MIS4_min-MIS4_max) over Africa. 

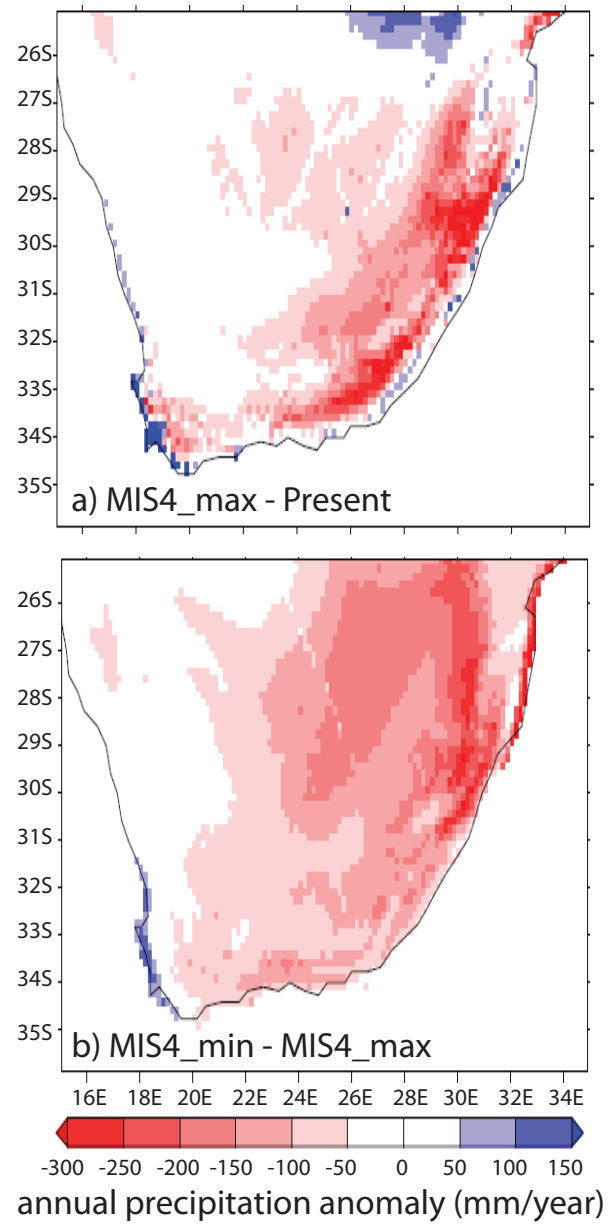

Figure 8. Annual precipitation $\left(\mathrm{mm} \mathrm{yr}^{-1}\right)$ simulated by IPSL_CM5A and downscaled to $0.16^{\circ}$ for (a) MIS4_max-present, and (b) MIS4_min-MIS4_max.

The increase in boreal summer insolation (JJA) in the Northern Hemisphere (Fig. 1) leads to higher temperatures over Africa north of $30^{\circ} \mathrm{N}$ (Fig. 7a) and to the intensification of the northern African monsoon in response to the enhancement of the land-sea temperature contrast. Precipitation over the Sahel is intensified and shifted northward, due to the enhancement of the monsoon winds. Precipitation around $4^{\circ} \mathrm{N}$ decreases as moisture is advected more inland, whereas we observe a positive precipitation anomaly around $10^{\circ} \mathrm{N}$. The negative anomaly in temperature in the same latitude band is caused by the increase in the latent heat flux associated to the wetter conditions. The mechanism described here is qualitatively similar to the simulation results of Marzin and Braconnot (2009b) for the Holocene. We leave the detailed investigation of the differences in the northern African monsoon sensitivity to precession for the Holocene or MIS4 boundary conditions for another study. We simply point out here the persistence of the mechanism for the MIS4 glacial conditions.
During the austral summer (DJF) the negative insolation anomaly over both hemispheres in MIS4_min compared to MIS4_max (Fig. 1) leads to a global cooling over Africa (Fig. $7 \mathrm{~b}$ ), ranging from -1 to $-4{ }^{\circ} \mathrm{C}$, depending on the region considered. For precipitation, the model simulates drier conditions south of $5^{\circ} \mathrm{N}$, over the regions under the influence of the ITCZ during DJF. This drying can be linked to the lower temperatures, causing a decrease in the intensity of the convection. Thus, our results show an opposite response of the northern African monsoon and the southern African monsoon to precession changes, at least for the MIS4 glacial boundary conditions.

After downscaling, the climate simulated in southern Africa in the summer rainfall region (eastern part) for MIS4_max is drier than the modern one, with total annual rainfall anomalies between -50 and $-300 \mathrm{~mm} \mathrm{yr}^{-1}$ (Fig. 8a). The decrease of precession (MIS4_minMIS4_max) leads to an additional drying in the east (from -100 to $-200 \mathrm{~mm} \mathrm{yr}^{-1}$ over most part of the summer rainfall area) and in the center (from -50 to $-100 \mathrm{~mm} \mathrm{yr}^{-1}$ around $22^{\circ}$ E) (Fig. 8b). Figure 9 presents the annual cycle of the downscaled temperature and precipitation over the area of summer rainfall (DJF) for MIS4_max and MIS4_min. The precession decrease leads to a decrease of the amplitude of the seasonal cycle of both temperature and precipitation. The austral summer (DJF) is drier and cooler, with a maximum precipitation decrease in December and January of 40 and $35 \mathrm{~mm} \mathrm{month}^{-1}$ respectively, i.e., a decrease of 37 and $46 \%$. The drying is accompanied by a $3{ }^{\circ} \mathrm{C}$ cooling in the monthly temperature. No significant changes in precipitation or temperatures occur during the winter months (JJA).

Our results confirm a strong impact of precession on the hydrological cycle of the region. The simulations results are in qualitative agreement with the data from the Pretorian Saltpan, in the north of southern Africa (Partridge et al., 1997; Kristen et al., 2007). The analysis of the lacustrine sediments from this site, covering the last $200000 \mathrm{yr}$, show periodic variations between wet and dry periods at the precessional frequency ( $23 \mathrm{ky}$ ). However, absolute dating, based on radio-carbon analysis, only covers the first $43 \mathrm{ky}$ of the sequence, preventing the determination of a precise phasing relationship between rainfall and precession changes. Kristen et al. (2007) have suggested that precipitation changes at the Pretorian Saltpan could be related to changes in the intensity and/or the length of the rainy season in that region. Our IPSL_CM5A simulations does not show changes in the length of the rainy season when precession decreases, but rather a flattening of the hydrological cycle with less intense rainfall from November to March. Partridge et al. (1997) have estimated the sensitivity of the southern African summer rainfall to insolation changes to 4.5 (i.e., $1 \%$ increase in summer insolation produces $4.5 \%$ precipitation increase). The annual downscaled precipitation in the region of the Pretorian Saltpan in MIS4_min and MIS4_max are 615 and $770 \mathrm{~mm} \mathrm{yr}^{-1}$ respectively, corresponding to a summer 

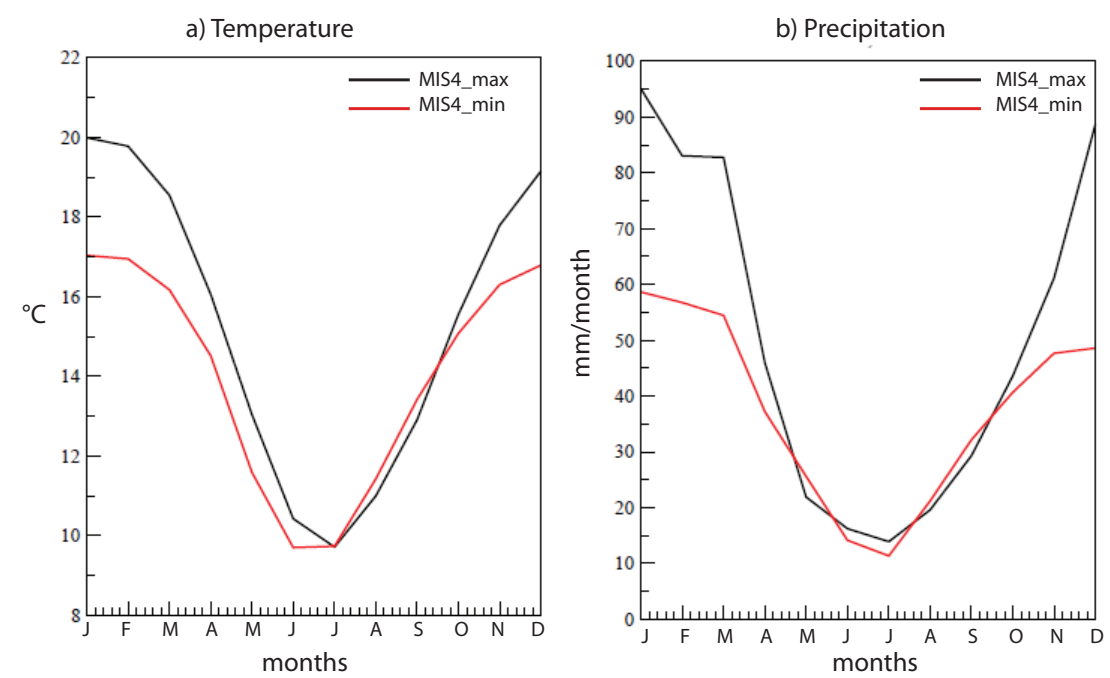

Figure 9. Annual cycle of (a) mean monthly temperatures $\left({ }^{\circ} \mathrm{C}\right)$ and (b) mean monthly precipitation (mm month ${ }^{-1}$ ) over the east of southern Africa (summer rainfall area, 37-25 $\mathrm{S}, 22-35^{\circ} \mathrm{E}$ simulated in MIS4_max (black) and MIS4_min (red) (IPSL_CM5A simulations, downscaled to $\left.0.16^{\circ}\right)$ ).

insolation at $30^{\circ} \mathrm{S}$ of 463 and $495 \mathrm{~W} \mathrm{~m}^{-2}$, i.e., a $25 \%$ precipitation increase for $7 \%$ insolation increase. The precipitation sensitivity coefficient computed from these values is thus 3.5, smaller than the results of Partridge et al. (1997) but of the same order of magnitude. However, even when the record from the Pretorian Saltpan is tuned on the precession variations, the reconstructed precipitation at the Pretorian Saltpan and insolation at $30^{\circ} \mathrm{S}$ diverge after $60 \mathrm{kyr}$. Our simulations thus correspond to the very last period where precession and summer rainfall in southern Africa seem to co-vary. However, since we performed only snapshot simulations, we cannot investigate the possible leads and lags between precession and precipitation changes to validate or invalidate the tuning of Partridge et al. (1997). AOGCMs are not suitable tools to investigate this issue, given their high computational cost. Simulations with faster AOGCMs would be required to perform transient runs and to investigate further the links between precession and precipitation in southern Africa over several precession cycles.

\subsubsection{Vegetation changes in southern Africa}

The vegetation pattern simulated over southern Africa for MIS4_max (Fig. 10a) is close to the one simulated for present day (Fig. 4b), with high tree fractions in the east. The high tree percentages in that region seem to be more in a qualitative agreement with pollen data for MIS4 than for present day. Indeed, pollen data from marine core MD962048 (off the eastern southern African coast; Dupont, 2011) show about $40 \%$ of tree pollen at the beginning of MIS4 vs. about $20 \%$ for present day. This observation suggests that part of the present day mismatches between the vegetation model and actual observations might indeed be attributed to anthropogenic effects (Sect. 3.2.1).

In MIS4_min (Fig. 10b, c) bare soil fractions increase southwards and eastwards at the expense of grasses and trees. In the center of southern Africa $\left(22^{\circ}-28^{\circ} \mathrm{E}\right)$ the model simulates increases in the bare soil fractions between 10 and $25 \%$. An increase of similar magnitude also occurs in the southwest. Decreases in tree fractions (between 5 and $25 \%$ ) occur on all grid cells where they are present in MIS4_max (Fig. 10c). The total decrease in the area occupied by trees over southern Africa is between about 18-19\% for the evergreen woody PFTs and $30 \%$ for the summergreen trees (Fig. 11a). Grass fractions decrease by $5-15 \%$ in the center and southwest but increase in the east and south at the expense of trees (Fig. 10c). Overall, the total area covered by grasses over southern Africa decreases by about $7 \%$ (Fig. 11a).

The simulated increase in the bare soil fractions can be considered as a desertification of the landscape and is in qualitative agreement with pollen data off western southern Africa (marine core MD96-2098), which show an expansion in the semi-desert biomes (Urrego et al., 2014) when precession decreases during MIS4. Likewise, our results are in agreement with the increase in arboreal pollen off eastern southern Africa during the same period (marine core MD962048, Dupont, 2011).

The results of the sensitivity runs are synthesized in Fig. 11a, which shows the percentages of change in the total area occupied by the different PFTs for each simulation compared to MIS4_max. The diagrams show that relative impact of the different factors that we tested (precipitation, temperature, $\mathrm{CO}_{2}$ and insolation) depends on the PFT: 
a) MIS4_max
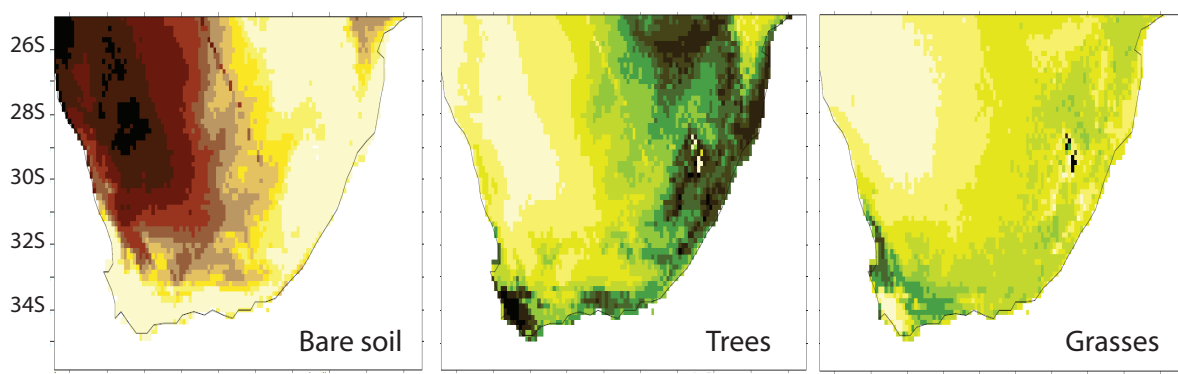

b) MIS4_min
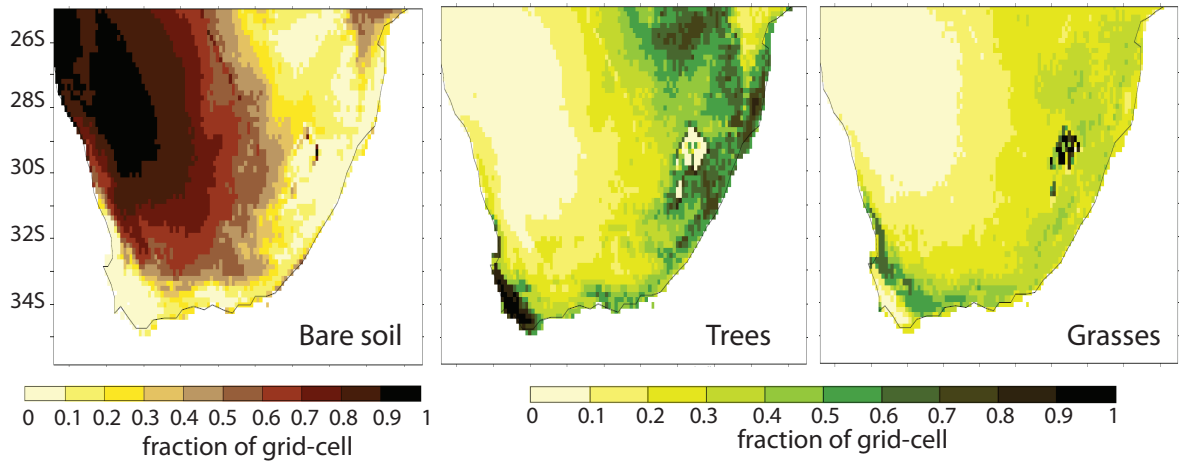

c) MIS4_min - MIS4_max
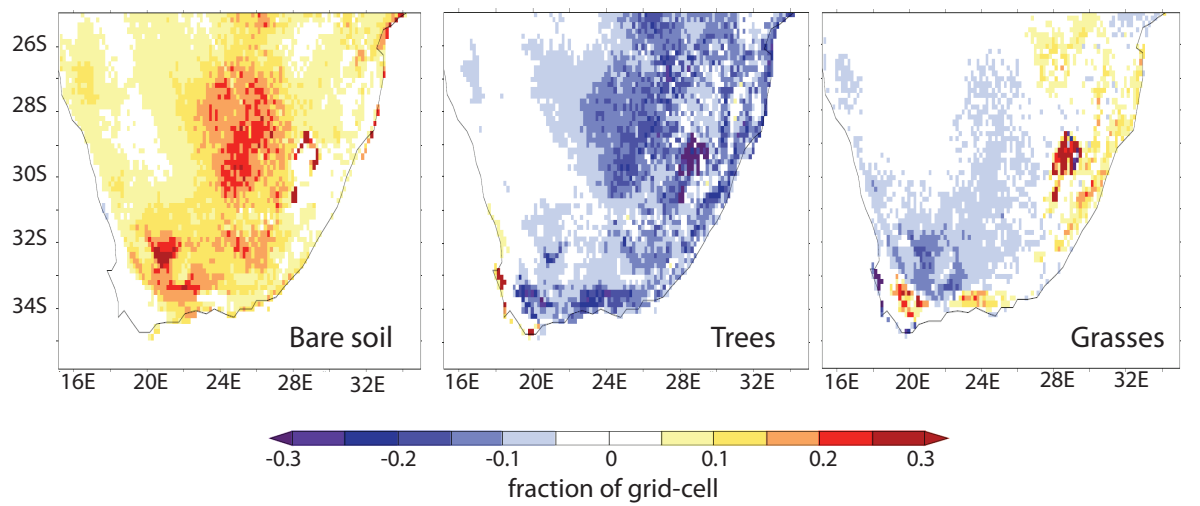

Figure 10. Vegetation cover (fraction of grid cell) simulated with LPJ-LMfire forced off-line. (a) MIS4_max, (b) MIS4_min, and (c) MIS4_min-MIS4_max.

- Trees: the $\mathrm{CO}_{2}$ decrease between MIS4_max and TEST_CO2 is only $30 \mathrm{ppm}$, but is responsible for a decrease between 3 and $7 \%$ for the three woody PFTs. This result is not very surprising given that LPJ is a DGVM rather sensitive to $\mathrm{CO}_{2}$ concentrations (e.g., Köhler et al., 2005). Temperature changes alone (TEST_TEMP) lead to an increase of the temperate needleleaf evergreen trees and the temperate broadleaf evergreen trees of +11 and $+4.5 \%$ respectively but to a small decrease of the temperate broadleaf summergreen trees $(-5 \%)$. Changes caused by insolation changes (TEST_INSOL) are smaller than $3 \%$ for the three temperate woody PFTs. The changes simulated in
TEST_PRECIP are close to the changes obtained for MIS4_min compared to MIS4_max.

- Grasses: the changes in the total area occupied by grasses for MIS4_min compared to MIS4_max is about $-7 \%$. The changes simulated in the different sensitivity runs compared to MIS4_max are small, with less than $1 \%$ of variations in TEST_PRECIP and TEST_TEMP and about $-3 \%$ in TEST_CO2 and TEST_INSOL.

Precipitation changes alone are sufficient to simulate a decrease in the surfaces occupied by the woody PFTs, similar to the decrease obtained for MIS4_min. Precipitation changes thus appear as the main factor driving the changes in tree fractions when precession decreases (MIS4_min- 

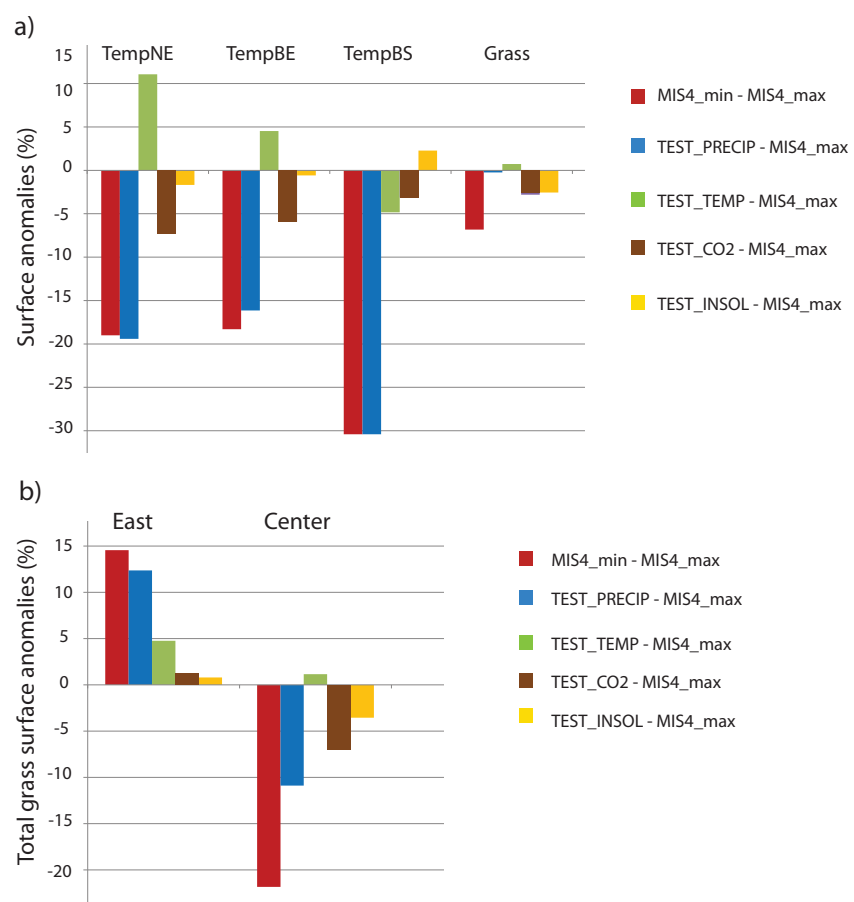

Figure 11. Percentage of changes in (a) the total surface occupied by temperate needleleaved trees (TempNE), temperate broadleaved evergreen trees (TempBE), temperate broadleaved summergreen trees (TempBS) and grasses; (b) the total surface occupied by grasses in the east $\left(34-25^{\circ} \mathrm{S}, 27-34^{\circ} \mathrm{E}\right)$ and in the center $\left(33-25^{\circ} \mathrm{S}, 19-27^{\circ} \mathrm{E}\right)$ of southern Africa, in MIS4_min, TEST_PRECIP, TEST_TEMP, TEST_CO2 and TEST_INSOL compared to MIS4_max.

MIS4_max). The relative impact of temperature, insolation and $\mathrm{CO}_{2}$ changes between MIS4_min and MIS4_max compensate each other. The sensitivity of grasses at the scale of southern Africa as a whole to the different factors tested is less clear. In particular, contrary to the woody PFTs, grasses seem to be insensitive to precipitation changes. However, this result hides important spatial differences between the east, where grasses increase with precession decrease and the central areas, where grass fractions decrease (Fig. 10). In the eastern part, precipitation decrease is the main driver of the expansion of grasses (Fig. 11b). In the center, the total decrease in grass surface is about $-22 \%$. Precipitation changes alone lead to a decrease of $-10 \%$ and the $\mathrm{CO}_{2}$ decrease to a decrease of $-7 \%$. These differences in the response of grass between the east and the center of southern Africa can be explained by the vegetation dynamics and the competition with the woody PFTs. In the east, the precipitation decrease drives the regression of trees but grasses have smaller water requirements and can expand on the space left by the woody PFTs. In the center, where annual precipitation is lower, the drying of climate affects both grasses and trees and the first driver of the regression of grasses is the precipitation decrease. How-

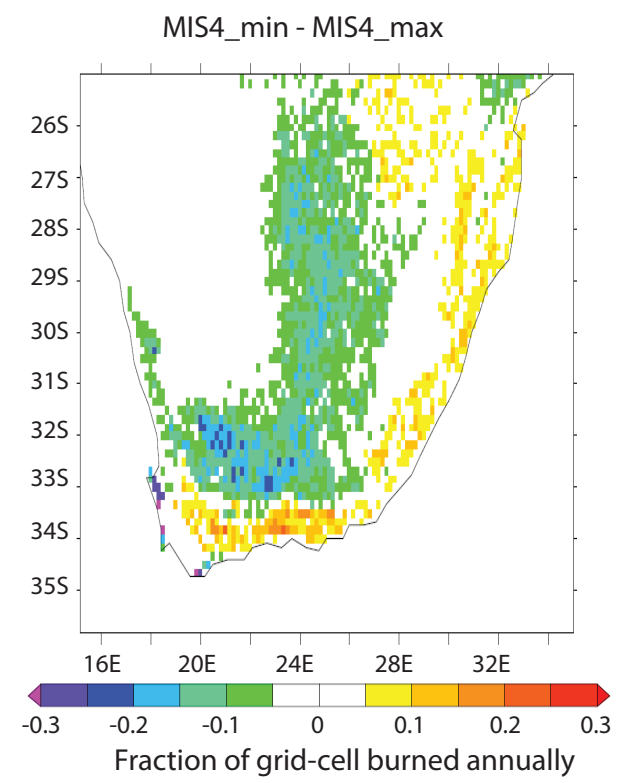

Figure 12. Difference (MIS4_min-MIS4_max) in the percentages of a grid cell burned during a year when precession decreases.

ever, the impact of the $\mathrm{CO}_{2}$ decrease is of similar magnitude and appears as an important factor to explain grass changes.

\subsubsection{Fire activity changes in southern Africa}

Figure 12 shows changes in the percentages of a grid cell burned annually when precession decreases (MIS4_minMIS4_max). The LPJ-LMfire model simulates a decrease in fire activity in the center of southern Africa (from -5 to $-20 \%$ ) and an increase in the east and south (from +5 to $+10 \%$ ). The comparison between Figs. 12 and 10 shows that fire activity increases when grass fractions increase and decreases where grass and/or tree fractions decrease. As mentioned in the previous section, the grass increase in the east and south merely reflects the regression of trees and is therefore strongly dependent on the vegetation's initial state in MIS4_max.

To better visualize this relationship between vegetation changes and fire activity we have plotted the changes in bare soil, tree and grass fractions against changes in the annual burned surface on Fig. 13a. The graph clearly shows a decrease in burned fractions over grid cells where bare soil fractions increase and tree and grass fractions decrease, and an increase in burned fractions with higher grass fractions (Fig. 13a). On the contrary, no clear relationship appears between the amplitude of the annual precipitation changes and the fire activity (Fig. 13b). This can be attributed to a different vegetation response in the east and in the center of southern Africa. In the east, despite the precipitation decrease, the climate is still wet enough to allow an increase of grass (i.e., easily incinerable fuels), whereas in the center the climate 

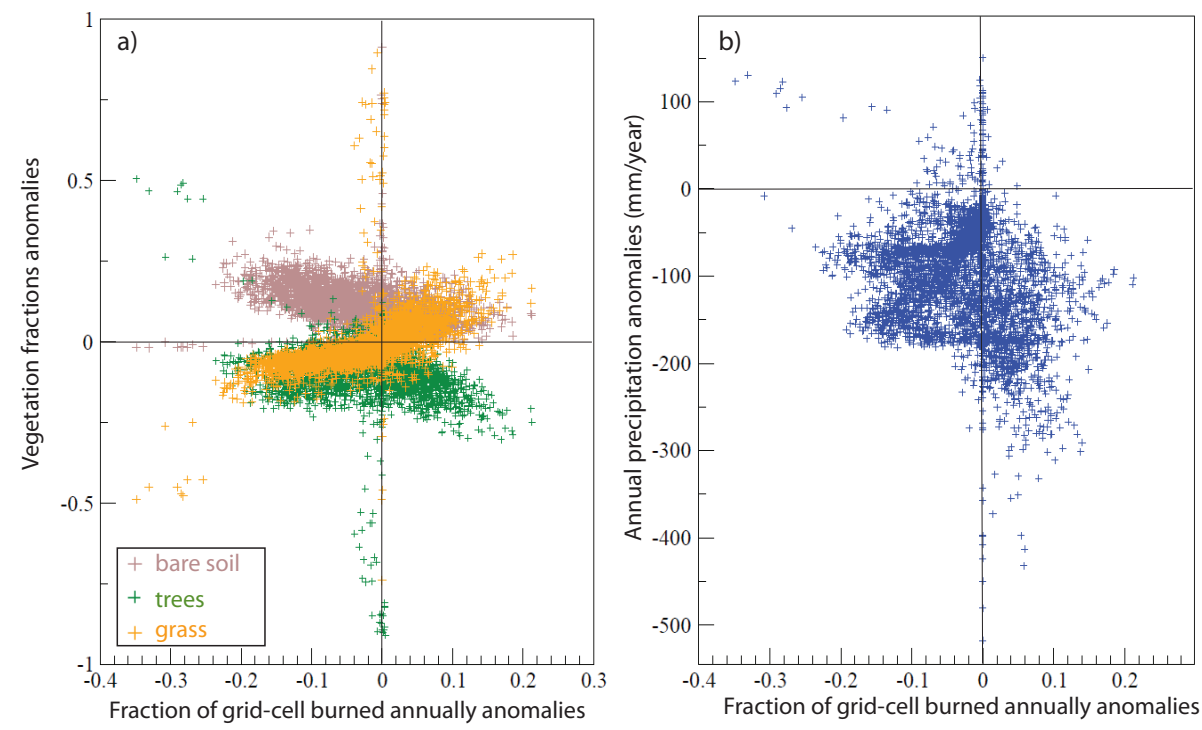

Figure 13. (a) Anomalies in the fraction of a grid cell occupied by bare soil (brown), trees (green), grasses (yellow) vs. anomalies in the percentage of a grid cell burned annually (MIS4_min-MIS4_max). (b) Total annual precipitation anomalies (mm yr ${ }^{-1}$ ) vs. anomalies in the percentage of a grid cell burned annually (MIS4_min-MIS4_max).

has become too dry and grasses decline, leading to smaller amounts of light fuel and a decrease of fire.

At the scale of the whole southern Africa, the dominant signal is the regression of grass-fueled fires in response to the precipitation decrease in the summer rainfall area, in qualitative agreement with Daniau et al. (2013). The simulations confirm the link between precession and fire activity, inferred from the microcharcoal record. As discussed in Daniau et al. (2013), the record can reflect either shifts in grassland extent or shifts in grassland productivity. Daniau et al. (2013) conclude that the latter hypothesis was the most likely. Our modeling results support this conclusion. Indeed, LPJ-LMfire simulates changes in vegetation fractions mainly limited to $5-15 \%$ for trees and 5-10\% for grasses (Fig. 10c) in most parts of southern Africa. Such percentages reflect changes in the productivity and density of the PFTs, but are not large enough to be interpreted as biome shifts.

Our results suggest that precession decrease appears to impact fire activity mainly indirectly, via changes in fuel load, rather than directly via changes in humidity. It confirms that vegetation response to climate changes have to be taken into account to investigate fire changes and highlight the importance of fuel load and how increased dryness can paradoxically lead to a decrease in fire activity in southern Africa.

Such a conclusion has been previously suggested for the last $21 \mathrm{kyr}$ (Turner et al., 2008) and during the last glacial period (Daniau et al., 2007) in the Mediterranean region.

\section{Conclusions}

We have performed two simulations of the MIS4 climate with the AOGCM IPSL_CM5A, for a maximum and minimum of the climatic precession index, and analyzed the simulated climatic changes over Africa, with a focus on southern Africa. The decrease of the precession index leads to an increase of boreal summer insolation in the Northern Hemisphere and to an intensification of the northern African monsoon. On the contrary, insolation decrease during austral summer leads to a cooling over Africa and to a decrease in the convective activity associated to the ITCZ, leading to a decrease of precipitation over the regions under its influence, including the east of southern Africa. Thus, our results show an anticorrelation between the northern and southern African monsoons in response to precession changes for the MIS4 glacial boundary conditions.

The IPSL_CM5A outputs have been statistically downscaled or interpolated to obtain high-resolution fields. These fields are used as input for the dynamic vegetation model LPJ-LMfire, to simulate vegetation and fire changes over southern Africa in response to precession changes.

The simulated potential present-day vegetation presents some biases compared to observations, but the model-data discrepancies are probably mostly due to the anthropogenic impact on the modern southern African vegetation. For our MIS4 vegetation simulations we can achieve the following conclusions, in qualitative agreement with observations: (i) precession decrease leads to a decrease of precipitation during austral summer in eastern southern Africa (summer rainfall area). No significant precipitation changes occur during the dry season. (ii) The dryness increase causes an 
expansion of bare soil, which can be interpreted as a desertification, and a decrease in trees and grass fractions in the center of southern Africa. In the east, the model simulates an expansion of grasses in response to the precession decrease, due to their development on grid cells where tree cover declines. (iii) The simulated fire activity over southern Africa is strongly dependent on the vegetation type (i.e., fuel load) and decreases (increases) on grid cells where grass fractions decrease (increase).

The results provided here show important climatic and environmental changes in southern Africa between the beginning and end of MIS4. How they could have affected the early human populations in that region could be tackled through ecological niche modeling (Banks et al., 2008). However, our simulations do not take into account the impact of millennial-scale variability, which is superimposed to the long-term orbitally driven climatic changes and was recently suggested as a driver of technological innovations (Ziegler et al., 2013). This issue requires supplementary runs with the IPSL_CM5A model, similar to the freshwater-hosing experiments that have been performed with the older version of the GCM and for last glacial maximum conditions (Kageyama et al., 2009; Woillez et al., 2013).

\section{The Supplement related to this article is available online at doi:10.5194/cp-10-1165-2014-supplement.}

Acknowledgements. The present manuscript is a contribution to the TRACSYMBOLS project, supported by the European research council, TRACSYMBOLS no. 249587. This work also benefited from the HPC resources of CCRT and IDRIS made available by GENCI (Grand Equipement National de Calcul Intensif), CEA (Commissariat a l'Energie Atomique et aux Energies Alternatives) and CNRS (Centre National de la Recherche Scientifique). We thank Olivier Marti for his help in the construction of the correct boundary conditions for the GCM, Jed Kaplan for providing the LPJ-LMfire model and Stefan Kern for providing MODIS files. We also thank two anonymous reviewers for their comments to improve this manuscript.

Edited by: V. Brovkin

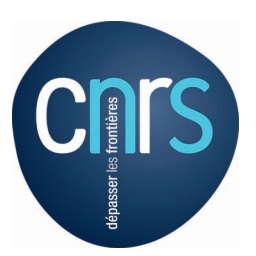

The publication of this article is financed by CNRS-INSU.

\section{References}

Amante, C. and Eakins, B.: Etopo1-1 arc-minute global relief model: procdures, data sources and analysis, Technical report,
National Geophysical Data Center, NESDIS, NOAA, US Department of Commerce, National Geophysical Data Center, Boulder, Colorado, 2008.

Archibald, S., David, R., Van Wilgen, B., and Scholes, R.: What limits fire? an examination of drivers of burnt area in southern africa, Global Change Biol., 15, 613-630, 2009.

Archibald, S., Scholes, R., Roy, D., Roberts, G., and Boschetti, L.: Southern African fire regimes as reaveled by remote sensing, J. Wildland Fire, 19, 861-878, 2010.

Archibald, S., Staver, A., and Levin, S.: Evolution of human-driven fire regimes in africa, Proc. Natl. Acad. Sci., 109, 847-852, 2012.

Argus, D. and Peltier, W.: Constraining models of postglacial rebound using space geodesy: a detailed assessment of model ICE5G (VM2) and its relatives, Geophys. J. Int., 181, 697-723, 2010.

Banks, W., d'Errico, F., Townsend Peterson, A., Vanhaeren, M., Kageyama, M., Sepulchre, P., Ramstein, G., Jost, A., and Lunt, D.: Human ecological niches and ranges during the LGM in Europe derived from an application of eco-cultural niche modeling, J. Archeol. Sci., 35, 481-491, 2008.

Bond, W., Midgley, G., and Woodward, F.: The importance of low atmospheric $\mathrm{CO}_{2}$ and fire in promoting the spread of grasslands and savannas, Global Change Biol., 9, 973-982, 2003a.

Bond, W., Midgley, G., and Woodward, F.: What controls South African vegetation - climate or fire ?, South Afr. J. Botany, 69, 79-91, 2003b.

Braconnot, P. and Marti, O.: Impact of precession on monsoon characteristics from coupled ocean atmosphere experiments: changes in Indian monsoon and Indian ocean climatology, Mar. Geol., 13, 23-24, 2003.

Braconnot, P., Joussaume, S. de Noblet, N., and Ramstein, G.: MidHolocene and last glacial maximum African monsoon changes as simulated within the Paleoclimate modelling intercomparison project, Global Planet. Changes, 26, 51-66, 2000.

Cheng, M. and Qi, Y.: Frontal Rainfall-Rate Distribution and some conclusions on the threshold method, J. Appl. Meteorol., 41, 1128-1139, 2002.

Christian, H., Blakeslee, R., Boccippio, D., Boeck, W., Buechler, D., Driscoll, K., Goodman, S., Hall, J., Koshak, W., Mach, D., and Stewart, M.: Global frequency and distribution of lightning as observed from space by the optical transient detector, J. Geophys. Res.-Atmos. (1984-2012), 108, ACL4-1-ACL4-15, 2003.

Compo, G., Whitaker, J., Sardeshmukh, P., Matsui, N., Allan, R., Yin, X., Gleason, B., Vose, R., Rutledge, G., Bessemoulin, P., Brönnimann, S., Brunet, M., Crouthamel, R., Grant, A., Groisman, P., Jones, P., Kruk, M., Kruger, A., Marshall, G., Maugeri, M., Mok, H., Nordli, E., Ross, T., Trigo, R., Wang, X., Woodruff, S., and Worley, S.: The Twentieth Century Reanalysis Project, Q. J. Roy. Meteorol. Soc., 137 1-28, 2011.

Cowling, R., Richardson, D., and Pierce, S. (Eds.): Vegetation of Southern Africa, Cambridge University Press, 1997.

: (1999). Physiological significance of low atmospheric $\mathrm{CO}_{2}$ for plant-climate interactions, Quaternary Res., 52, 237-242, 1999.

Daniau, A.-L., Sanchez-Goñi, M.-F., Beaufort, L., LaggounDéfarge, F., Loutre, M.-F., and Duprat, J.: Dansgaard-Oeschger climatic variability revealed by fire emissions in southwestern Iberia, Quaternary Sci. Rev., 26, 1369-1383, 2007.

Daniau, A.-L., Sánchez-Goì, M.-F., Martinez, P., Urrego, D., BoutRoumazeilles, V., Desprat, S., and Marlon, J. R.: Orbital-scale 
climate forcing of grassland burning in southern africa, Proc. Natl. Acad. Sci., 110, 5069-5073, 2013.

d'Errico, F. and Henshilwood, C.: Additional evidence for bone technology in the southern African middle stone age, J. Human Evolut., 52, 142-163, 2007.

Dufresne, J.-L., Foujols, M.-A., Denvil, S., Caubel, A., Marti, O., Aumont, O., Balkanski, Y., Bekki, S., Bellenger, H., Benshila, R., Bony, S., Bopp, L., Braconnot, P., Borckmann, P., Cadule, P., Cheruy, F., Codron, F., Cozic, A., Cugnet, D., de Noblet, N., Duvel, J.-P., Ethé, C., Fairhead, L., Fichefet, T., Flavoni, S., Friedlingstien, P., Grandpeix, J.-Y., Guez, L., Guilyardi, E., Hauglustaine, D., Hourdin, F., Idelkadi, A., Ghattas, J., Joussaume, S., Kageyama, M., Krinner, G., Labetoulle, S., Lahellec, A., Lefebvre, M.-P., Lefevre, F., Levy, C., Li, Z., Lloyd, J., Lott, F., Madec, G., Mancip, M., Marchand, M., Masson, S., Meurdesoif, Y., Mignot, J., Musat, I., Parouty, S., Polcher, J., Rio, C., Schultz, M., Swingedouw, D., Szopa, S., Talandier, C., Terray, P., Viovy, N., and Vuichard, N.: Climate change projections using the IPSL-CM5 Earth system model with an emphasis on changes between CMIP3 and CMIP5, Clim. Dynam., 40, $2123-$ $2165,2013$.

Dupont, L.: Orbital scale vegetation change in Africa, Quaternary Sci. Rev., 30, 3589-3602, 2011.

Fichefet, T. and Morales-Maqueda, A.-M.: Sensitivity of a global sea ice model to the treatment of ice thermodynamics and dynamics, J. Geophys. Res., 102, 12609-12646, 1997.

Fichefet, T. and Morales-Maqueda, A.-M.: Modelling the influence of snow accumulation and snow-ice formation on the seasonal cycle of the antarctic sea-ice cover, Clim.e Dynam., 15, 251-268, 1999.

Gasse, F.: Hydrological changes in the African tropics since the Last Glacial Maximum, Quaternary Sci. Rev., 19, 189-211, 2000.

Giglio, L., Randerson, J. T., van der Werf, G. R., Kasibhatla, P. S., Collatz, G. J., Morton, D. C., and DeFries, R. S.: Assessing variability and long-term trends in burned area by merging multiple satellite fire products, Biogeosciences, 7, 1171-1186, doi:10.5194/bg-7-1171-2010, 2010.

Harrison, S. and Prentice, C.: Climate and $\mathrm{CO}_{2}$ controls on global vegetation distribution at the last glacial maximum : analysis based on palaeovegetationdata, biome modelling and palaeoclimate simulations, Global Change Biol., 9, 983-1004, 2003.

Hastie, T. and Tibshirani, R.: Generalized Additive Models, London: Chapman and Hall, 1990.

Henshilwood, C., d'Errico, F., Yates, R., Jacobs, Z., Tribolo, C., Duller, G., Mercier, N., Sealy, J., Valladas, H., Watts, I., and Wintle, A.: Emergence of modern human behavior: middle stone age engravings from South Africa, Science, 295, 1278-1280, 2002.

Henshilwood, C., d'Errico, F., and Watts, I.: Engraved ochres from the middle stone age levels at Blombos Cave. South Africa, J. Human Evolut., 57, 27-47, 2009.

Hourdin, F., Musat, I., Bony, S., Braconnot, P., Codron, F., Dufresne, J.-L., Fairhead, L., Filiberti, M.-A., Friedlingstein, P., Grandpeix, J.-Y., Krinner, G., LeVan, P., Li, Z., and Lott, F.: The LMDZ4 general circulation model: climate performance and sensitivity to parametrized physics with emphasis on tropical convection, Clim. Dynam., 27, 787-813, 2006.

Jacobs, Z., Roberts, R., Galbraith, R., Deacon, H., Grün, R., Mackay, A., Mitchell, P., Vogelsang, R., and Wadley, L.: Ages for the middle Stone age of southern Africa: implications for human behavior and dispersal, Science, 322, 733-735, 2008.

Jolly, D. and Haxeltine, A.: Effect of low glacial atmospheric $\mathrm{CO}_{2}$ on tropical African montane vegetation, Science, 276, 786-788, 1997.

Kageyama, M., Mignot, J., Swingedouw, D., Marzin, C., Alkama, R., and Marti, O.: Glacial climate sensitivity to different states of the Atlantic Meridional Overturning Circulation: results from the IPSL model, Clim. Past, 5, 551-570, doi:10.5194/cp-5-5512009, 2009.

Kageyama, M., braconnot, P., Bopp, L., Caubel, A., Foujols, M.A., Guilyardi, E., Khodri, M., Lloyd, J., Lombard, F., Mariotti, V., Marti, O., Roy, T., and Woillez, M.-N.: Mid-Holocene and Last Glacial Maximum climate simulations with the IPSL model - part I: comparing IPSL_CM5A to IPSL_CM4. Clim. Dynam., 40, 2447-2468, 2013a.

Kageyama, M., Braconnot, P., Bopp, L., Mariotti, V., Roy, T., Woillez, M.-N., Caubel, A., Foujols, M.-A., Guilyardi, E., Khodri, M., Lloyd, J., Lombard, F., and Marti, O.: Mid-Holocene and Last Glacial Maximum climate simulations with the IPSL model: part II: model-data comparisons. Clim. Dynam., 40, 2469-2495, 2013b.

Köhler, P., Joos, F., Gerber, S., and Knutti, R.: Simulated changes in vegetation distribution, land carbon storage, and atmospheric $\mathrm{CO}_{2}$ in response to a collapse of the North Atlantic thermohaline circulation, Clim. Dynam., 25, 689-708, 2005.

Krinner, G., Viovy, N., de Noblet-Ducoudré, N., J., O., Polcher, J., friedlingstein, P., Ciais, P., Sitch, S., and Prentice, I. C.: A dynamic global vegetation model for studies of the coupled atmosphere-biosphere system, Global Biogeochem. Cy., 19, GB1015, doi:10.1029/2003GB002199, 2005.

Kristen, I., Fuhrmann, A., Thorpe, J., Röhl, U., Wilkes, H., and Oberhänsli, H.: Hydrological changes in southern Africa over the last $200 \mathrm{Ka}$ as recorded in lake sediments from the Tswaing impact crater, South Afr. J. Geol., 110, 311-326, 2007.

Laskar, J., Robutel, P., Joutel, F., Gastineau, M., Correia, A., and Levrard, B.: A long term numerical solution for the insolation quantities of the Earth, Astronom. Astrophys., 428, 261-285, 2004.

Levavasseur, G., Vrac, M., Roche, D. M., Paillard, D., Martin, A., and Vandenberghe, J.: Present and LGM permafrost from climate simulations: contribution of statistical downscaling, Clim. Past, 7, 1225-1246, doi:10.5194/cp-7-1225-2011, 2011.

Liu, Y., Stanturf, J., and Goodrick, S.: Trends in global wildfire potential in a changing climate, Forest Ecol. Manage., 259, 685697, 2010.

Madec, G., Delecluse, P., Imbard, M., and Lévy, C.: OPA version 8.1 Ocean general circulation model reference manual, $91 \mathrm{pp}$., Number 11, Note du Pole de Modélisation, Institut Pierre-Simon Laplace, Institut Pierre Simon Laplace, France, 1998.

Martin, A., Vrac, M., Paillard, D., Dumas, C., and Kageyama, M.: Statistical-dynamical downscaling for Earth Models of Intermediate Complexity, submitted, 2011.

Marzin, C. and Braconnot, P.: The role of the ocean feedback on Asian and African monsoon variations at $6 \mathrm{kyr}$ and $9.5 \mathrm{kyr} \mathrm{BP}$, Compt. Rendus Geosci., 341, 643-655, 2009a.

Marzin, C. and Braconnot, P.: Variations of Indian and African monsoons induced by insolation changes at 6 and $9.5 \mathrm{kyr}$ BP, Clim. Dynam., 33, 215-231, 2009b. 
Masson, V., Braconnot, P., Jouzel, J., de Noblet, N., Cheddadi, R., and Marchal, O.: Simulation of intense monsoons under glacial conditions. Geophys. Res. Lett., 27, 1747-1750, 2000.

Mucina, L., Rutherford, M., and Powrie, L.: Vegetation Map of South Africa, Lesotho and Swaziland, 2nd Ed., South African National Biodiversity Institute Pretoria, 2007.

New, M., Lister, D., Hulme, M., and Makin, I.: A high-resolution data set of surface climate over global land areas, Clim. Res., 21, $1-25,2002$.

Oghaito, R. and Abe-Ouchi, A.: The role of ocean thermodynamics and dynamics in Asian summer monsoon changes during the Mid-Holocene, Clim. Dynam., 29, 39-50, 2007.

Partridge, T., Demenocal, P., Lorentz, S., Paiker, M., and Vogel, J.: Orbital forcing of climate over South Africa: a 200,000-year rainfall record from the Pretorian Saltpan, Quaternary Sci. Rev., 16, 1125-1133, 1997.

Petit, J., Jouzel, J., Raynaud, D., Barkov, N., Barnola, J., Basile, I., Bender, M., Chappellaz, J., Davis, M., Delaygue, G., Delmotte, M., Kotlyakov, V., Legrand, M., Lipenkov, V., Lorius, C., Pepin, L., Ritz, C., Saltzman, E., and Stievenard, M.: Climate and atmospheric history of the past 420,000 years from the Vostok ice core, Antarctica, Nature, 399, 429-436, 1999.

Pfeiffer, M., Spessa, A., and Kaplan, J. O.: A model for global biomass burning in preindustrial time: LPJ-LMfire (v1.0), Geosci. Model Dev., 6, 643-685, doi:10.5194/gmd-6-643-2013, 2013.

Prentice, I. C. and Harrison, S. P.: Ecosystem effects of $\mathrm{CO}_{2}$ concentration: evidence from past climates, Clim. Past, 5, 297-307, doi:10.5194/cp-5-297-2009, 2009.

Rutherford, M.: Categorization of biomes, Vegetation of Southern Africa, Cambridge University Press, Cambridge, 91-98, ISBN 0-521-57142-1, 1997.

Saporta, G.: Probabilités, Analyse des données et statistiques, Editions Technip, 1990.

Scholes, R.: Savanna, in: Vegetation of Southern Africa, edited by: Cowling, R. M., Richardson, D. M., and Pierce, S. M., Cambridge University Press, Cambridge, UK, 258-277, 1997.

Schwartz, G.: Estimating the dimension of a model, The Ann. Statist., 6, 461-464, 1978.

Sitch, S., Smith, B., Prentice, I., Arneth, A., Bondeau, A., Cramer, W., Kaplan, J., Levis, S., Lucht, W., Sykes, M., Thonicke, K., and Venevsky, S.: Evaluation of ecosystem dynamics, plant geography and terrestrial carbon cycling in the LPJ dynamic global vegetation model, Global Change Biol., 9, 161-185, 2003.

Spahni, R., Chappellaz, J., Stocker, T., Loulergue, L., Hausammann, G., Kawamura, K., Flückiger, J., Schwander, J., Raynaud, D., Masson-Delmotte, V., and Jouzel, J.: Atmospheric Methane and Nitrous Oxide of the Late Pleistocene from Antarctic Ice Cores, Science, 310, 1317-1321, 2005.

Thonicke, K., Spessa, A., Prentice, I. C., Harrison, S. P., Dong, L., and Carmona-Moreno, C.: The influence of vegetation, fire spread and fire behaviour on biomass burning and trace gas emissions: results from a process-based model, Biogeosciences, 7, 1991-2011, doi:10.5194/bg-7-1991-2010, 2010.

Titshall, L., O'Connor, T., and Morris, C.: Effect of long-term exclusion of fire and herbivory on the soils and vegetation of sour grassveld, Afr. J. Range Forage Sci., 17, 70-80, 2000.

Townsend, J., Carroll, M., DiMiceli, C., Sohlberg, R., Hansen, M., and DeFries, R.: Vegetation Contiuous Fields MOD44B, [2001-
2010] Percent Tree Cover, Collection 5, Version 1, University of Maryland, College Park, Maryland, 2001, downloaded 8 February 2013, provided on 0.05 degree Climate Modeling Grid in NetCDF by the Integrated Climate Data Center (ICDC, http: //icdc.zmaw.de) University of Hamburg, Hamburg, Germany, 2011

Turner, R., Roberts, N., and Jones, M.: Climatic pacing of Mediterranean fire histories from lake sedimentary microcharcoal, Global Planet. Change, 63, 317-324, 2008.

Urrego, D., Sanchez-Goñi, M.-F., Daniau, A.-L., Lechevrel, S., and Hanquiez, V.: Increased aridity in southwestern africa during the last-interglacial warmest periods, in progress, 2013.

Valcke, S.: OASIS3 user guide (prism_2-5), PRISM report no 2. Tech. rep. TR/CMGC/06/73, CERFACS, Toulouse, France, 60, 2006.

Vrac, M., Marbaix, P., Paillard, D., and Naveau, P.: Non-linear statistical downscaling of present and LGM precipitation and temperatures over Europe, Clim. Past, 3, 669-682, doi:10.5194/cp3-669-2007, 2007.

Waelbroeck, C., Labeyrie, L., Michel, E., Duplessy, J.-C., McManus, J., Lambeck, K., Balbon, E., and Labracherie, M.: Sealevel and deep water temperature changes derived from benthic foraminifera isotopic records, Quaternary Sci. Rev., 21, 295-305, 2002.

Wang, P., Clemens, S., Beaufort, L., Braconnot, P., Ganssen, G., Jian, Z., Kershaw, P., and Sarnthein, M.: Evolution and variability of the Asian monsoon system: state of the art and outstanding issues, Quaternary Sci. Rev., 24, 595-629, 2005.

Westfall, R., Everson, C., and Everson, T.: The vegetation of the protected plots at Thabamhlope Research Station, Afr. J. Botany, 2, 15-25, 1983.

White, F.: The vegetation of Africa: a descriptive memoir to accompany the Unesco/AETFAT/UNSO vegetation map of Africa, (Natural Resources Research: 20). Paris: United Nations Educational, Scientific and Cultural Organization, 356 p., 1983.

Wilby, R., Wigley, T., Conway, D., Jones, P., Hewitson, B., Main, J., and Wilks, D.: Statistical downscaling of general circulation model output: A comparison of methods, Water Resour. Res., 34, 2995-3008, 1998.

Woillez, M.-N., Kageyama, M., Krinner, G., de Noblet-Ducoudré, N., Viovy, N., and Mancip, M.: Impact of $\mathrm{CO}_{2}$ and climate on the Last Glacial Maximum vegetation: results from the ORCHIDEE/IPSL models, Clim. Past, 7, 557-577, doi:10.5194/cp7-557-2011, 2011.

Woillez, M.-N., Kageyama, M., Combourieu-Nebout, N., and Krinner, G.: Simulating the vegetation response in western Europe to abrupt climate changes under glacial background conditions, Biogeosciences, 10, 1561-1582, doi:10.5194/bg-10-1561-2013, 2013.

Wood, S.: Generalized Additive Models: A introduction with R, Chapman and Hall/CRC Press, 2006.

Ziegler, M., Simon, M., Hall, I., Barker, S., Stringer, C., and Zahn, R.: Development of middle stone age innovation linked to rapid climate change, Nat. Commun., 4, 1905, doi:10.1038/ncomms2897, 2013. 